حركة حماية المستهلك ودورها في نشر الوعي الإستهلاكي

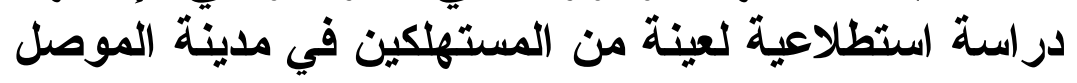

\author{
الدكتورة نجلة يونس محمد \\ أستاذ مساعد - قسم إدارة الأعمال \\ كلية الإدارة والاقتصاد - جامعة الموصل \\ Naglla2001@yahoo.com
}

يسعى البحث إلى التعرف على واقع حركة حماية المستهلتك في مدينة الموصل أخذاً بنظر

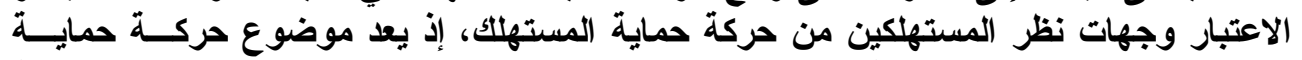

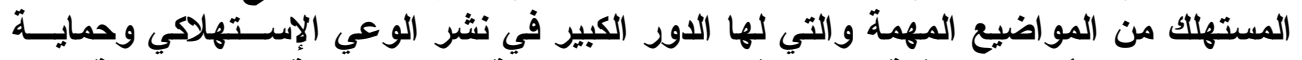

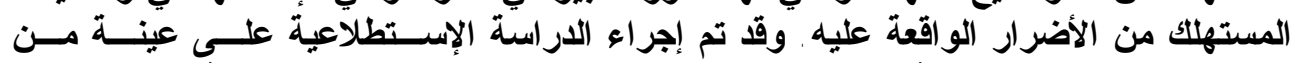

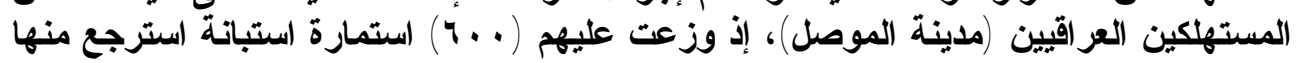

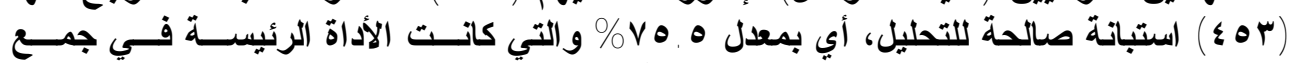

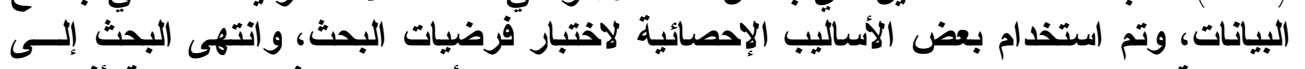

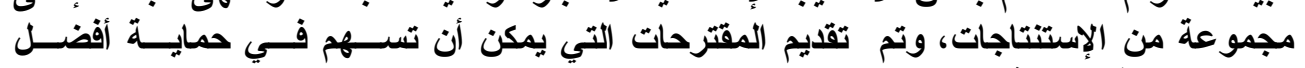
للمستهلك (في مدينة الموصل).

حماية المستهلك، الوعي الإستهلاكي.

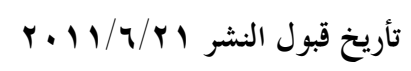

تأريخ استلام البحث ب r/1 / 1 ب r 


\title{
Consumer Movement Protection and Its Role on Consuming Awareness An Exploration Study for a Sample of Consumers Opinions in Mosul City
}

\author{
Najla Y. Al-Murad (PhD) \\ Assistant Professor \\ Department of Business Administration \\ University of Mosul
}

\begin{abstract}
This research tries to study the movement of consumer protection in Mosul City; it takes into consideration the consumers' opinions within the consumer protection movement. This subject is regarded as an important one; it has a prominent role in publishing the consumption awareness and consumer protection from the environment damages. A pilot study on Iraqi consumers has been conducted in Mosul City. A questionnaire of (600) consumers were distributed in Mosul City. The regained ones were (453) only (\%75.5). So, it was the major tool of data collection. Statistical methods were taken into account to test hypothesis, the research concluded a group of results and suggested possibilities to a better consumer's protection (in Mosul City).
\end{abstract}

\section{Key word:}

Consumer protection, consumption awareness.

المقدمة

يعد موضوع حماية المستهلك من المو اضبع المهمة و التي لها دور الكبير في الوعي

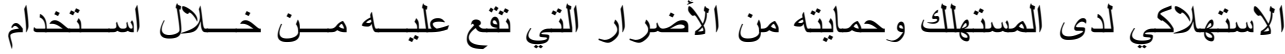

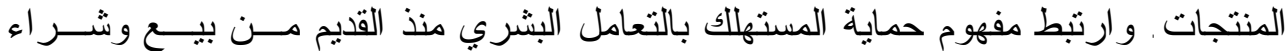

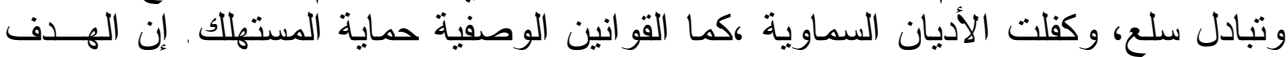
الأساسي من وراء حركة حماية المستهلك يتمنث في السعي لتحقيق أكبر منفعة للمستهلك، واكية

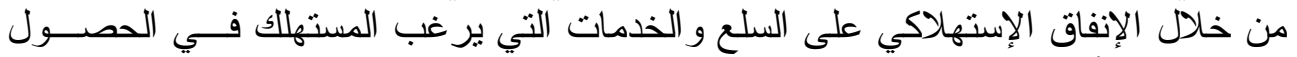

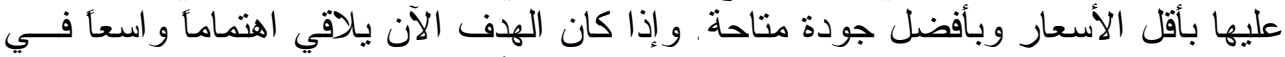

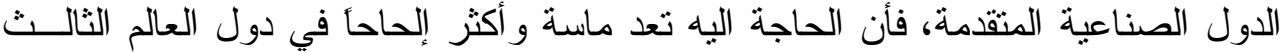

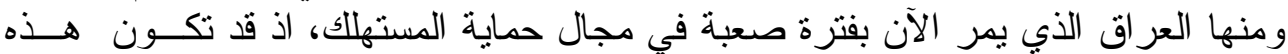

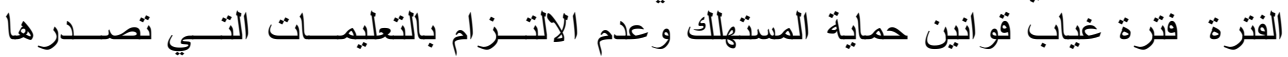
الوزار ات، و عدم وجود رقابة شاملة على جودة السلع و الخدمات المقدمة، من هنا ظهرت

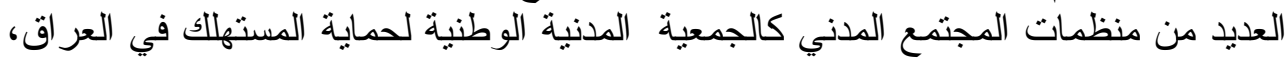
و الجمعية العر اقية للدفاع عن حقوق المستهلك و الجمعية العر اقية للتغذية وسلامة الخذاء .

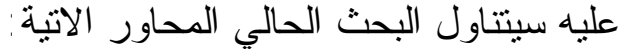

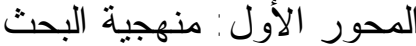
المحور الثاني: حماية المستهلك: : إطار مفاهيمي : المهي

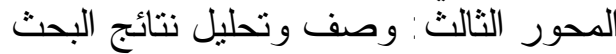
المحور الر ابع: الإستتناجات و المقترحات المحور الأول: منهجية البحث: الأنيتية 
مشكلة البحث

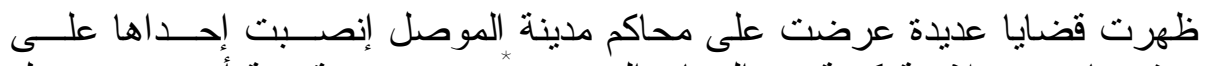

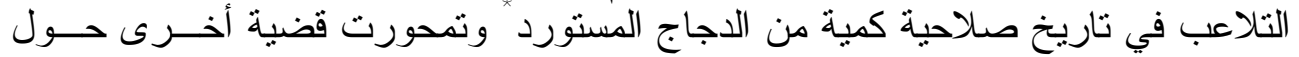

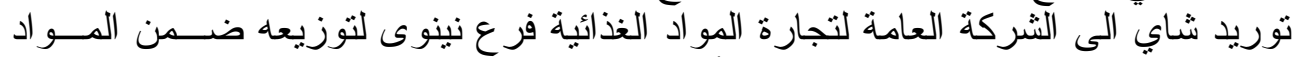

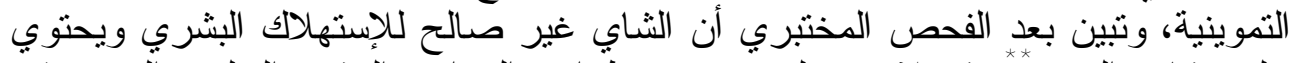

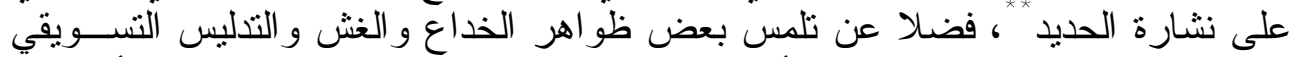

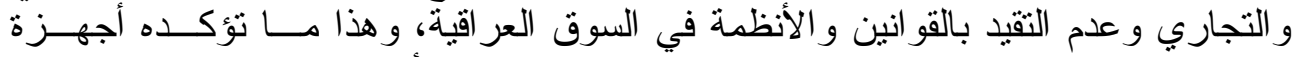

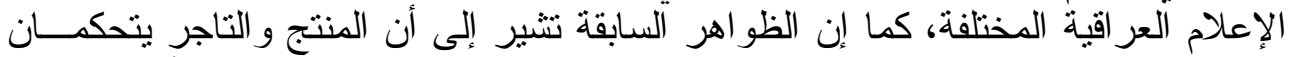

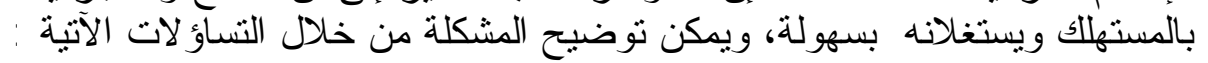

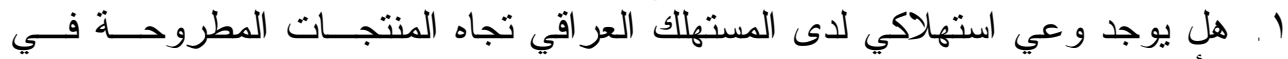

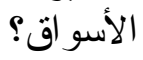

r. هل توجد رقابة حكومية على السوق العر اقية (مدينة الموصل)؟

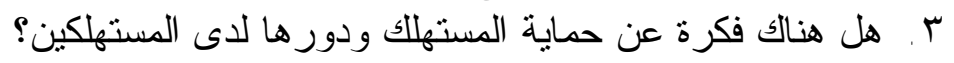

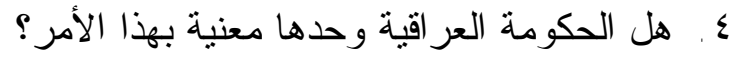

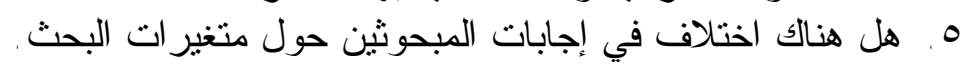

تتبع هذه الأهمية من الدور الذي يؤديه المستهلك في عملية البيع و الثر اء، و لاسيما

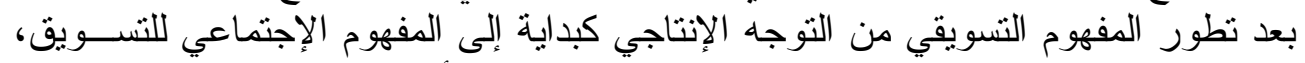

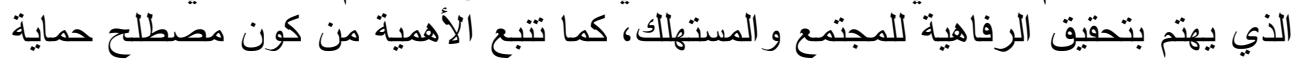

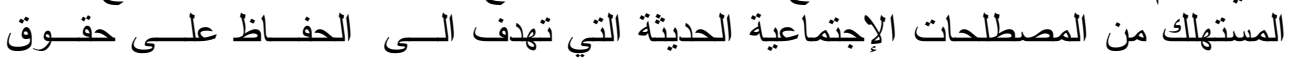

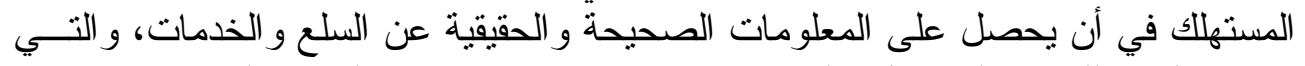

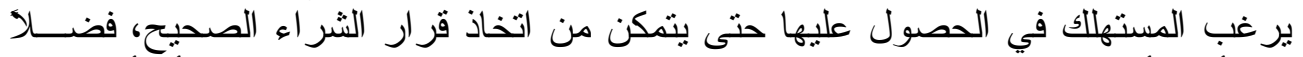

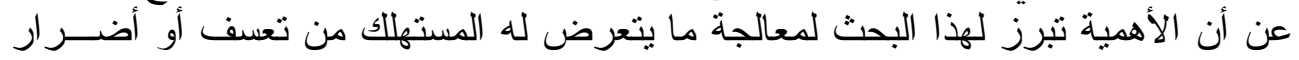

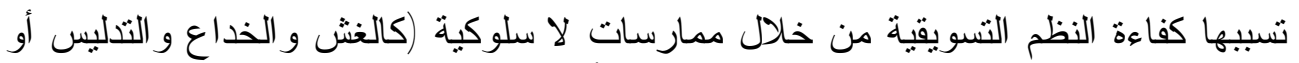

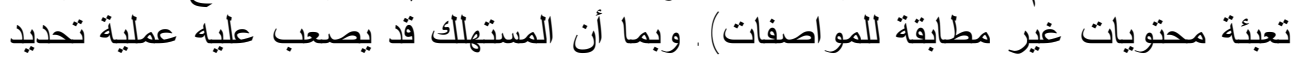

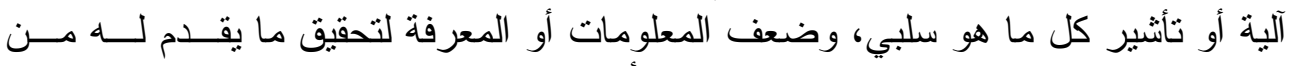

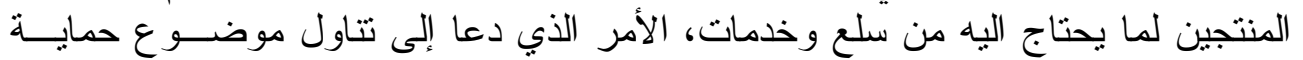

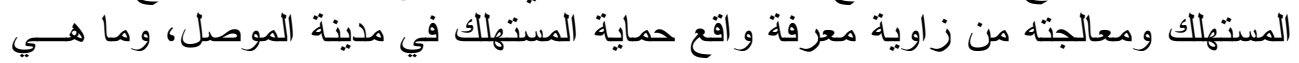
حقوقه؟ ومستوى تطبيق هذه الحقوق.

يهذف البحث إلى التعرف على و اقع حركة حماية المستهلك في العراق تحديداً فـي

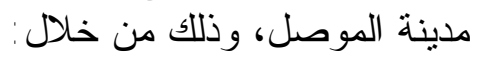
ا ـ التعرف على الوعي الإستهلاكي للمستهلك العر اقي في مدينة الموصل . * أحبلت هذه القضية إلى هيئة هنظمة التجارة في نينوى، و أدين التاجر على وفق أحكام قــانون تتظـــيم

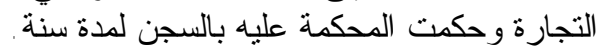
** هذه القضية ماز الت قيد التحقيق في هيئة النز اهة في محافظة نينوى . 
r. التعرف على طبيعة حقوق المستهللك ومستوى تحققها.

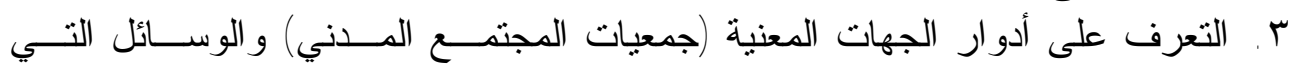

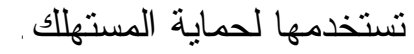
ع. . الإسهام مع جهود الآخرين في حماية المستهلك في العراق من خلال تقديم الإقتراحات

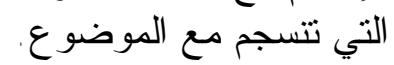
0. التعرف على إجابات المبحوثين حول متغير ات البحث.

فرضيات البحث

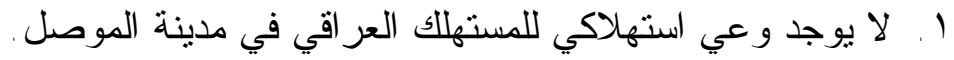

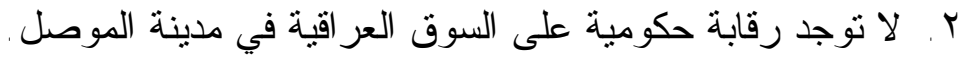

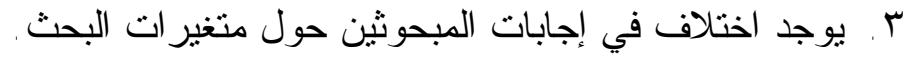

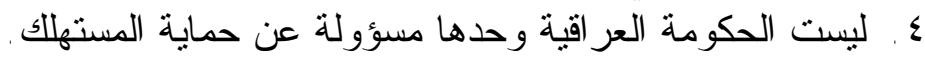

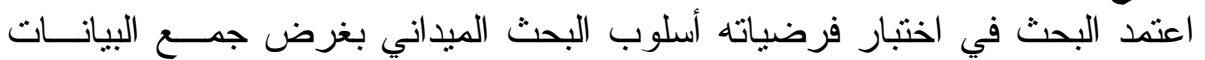
أساليب جمع البيانات

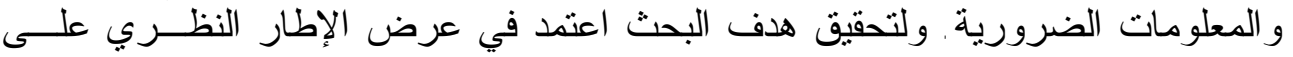

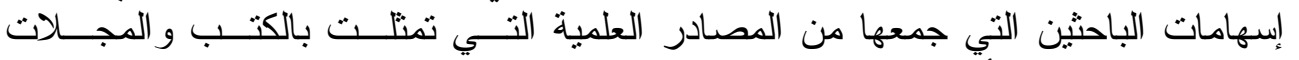

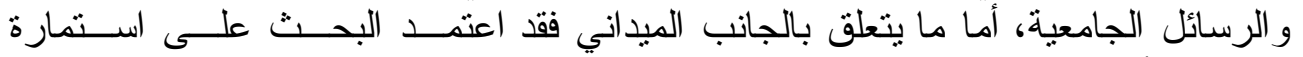

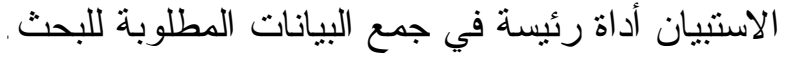

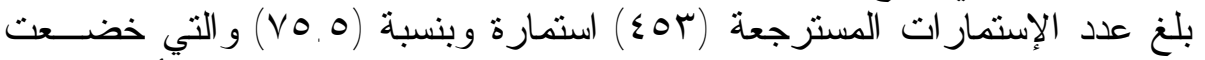

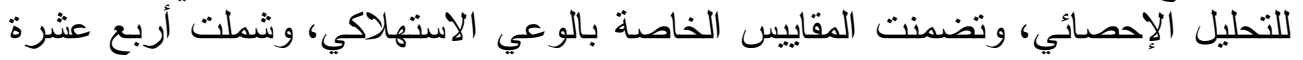

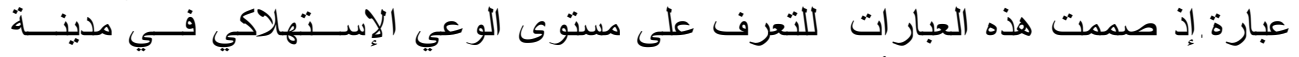

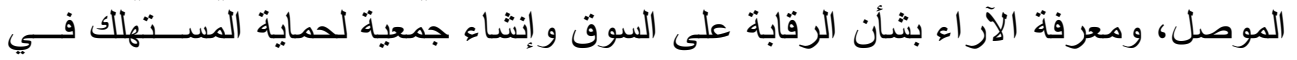

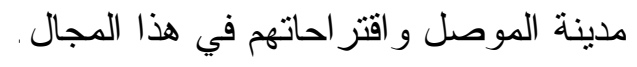

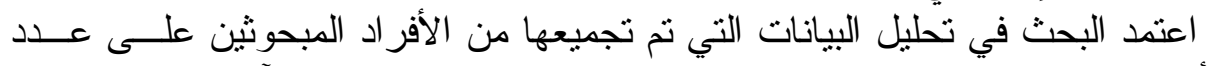

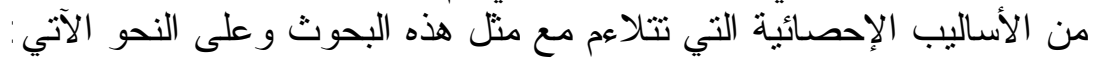

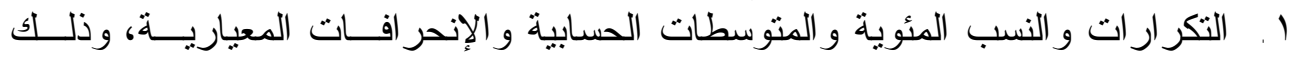

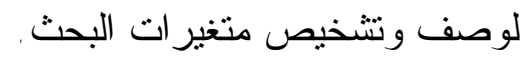
r. اختبار t لقياس معنوية العبار ات المستخدمة.

حركة حماية المستهلك: إطار مفاهيمي

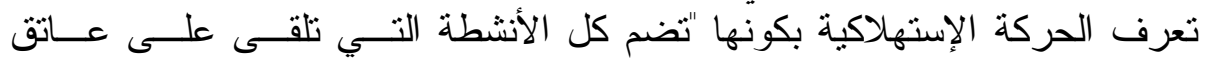

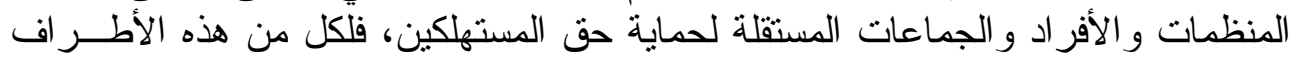

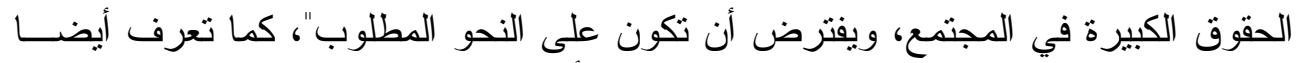

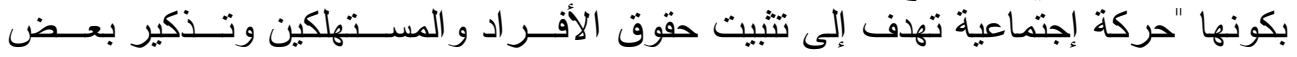

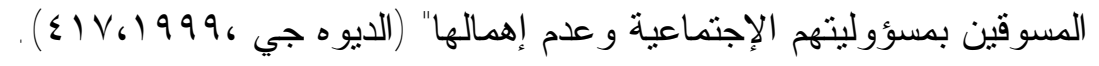


أولاً - التطور التاريخي لحركة حماية المستهلتك

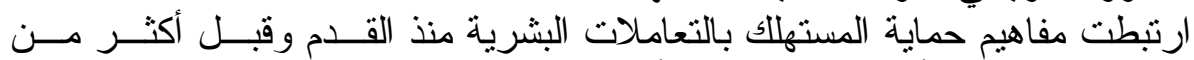

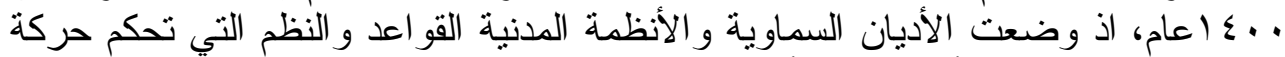

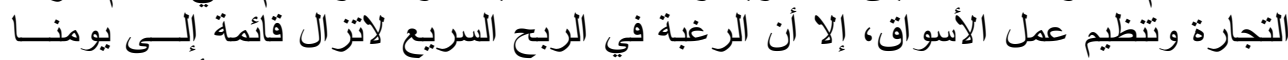

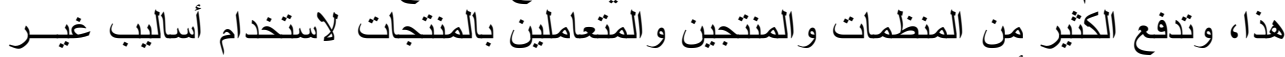

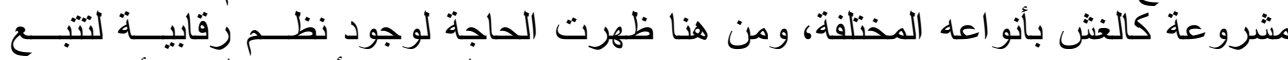

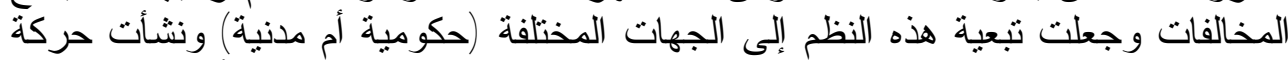

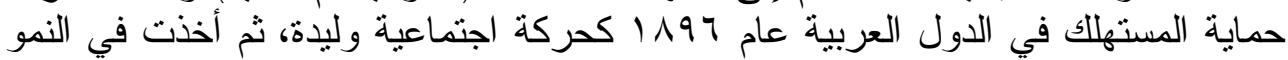

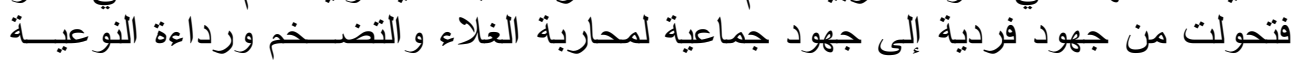

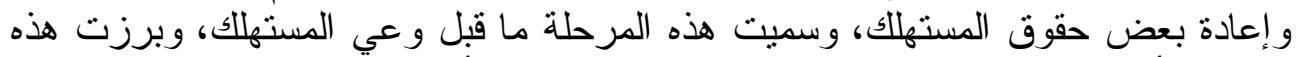

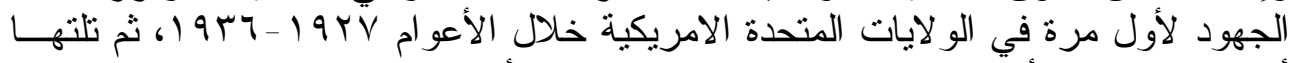

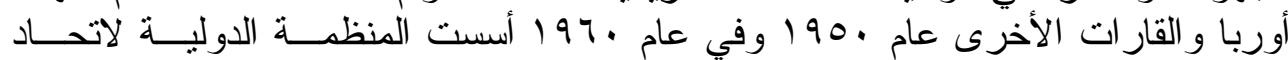

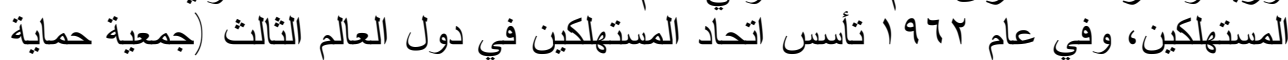

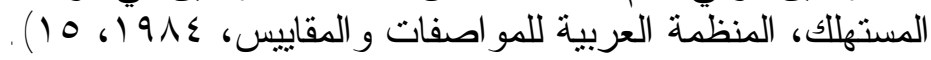

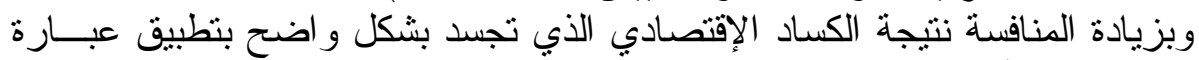

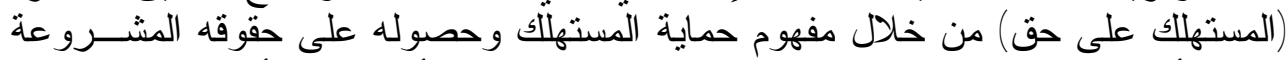

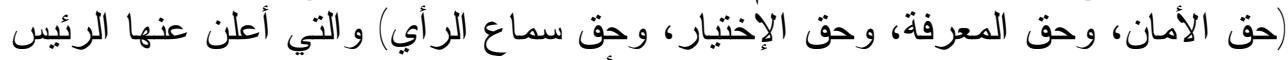

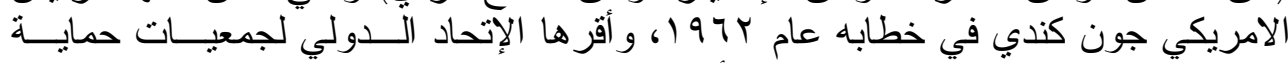

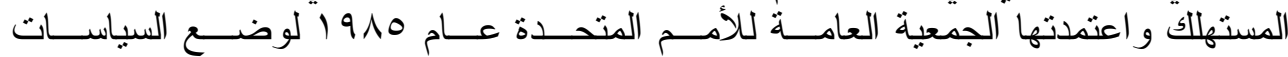

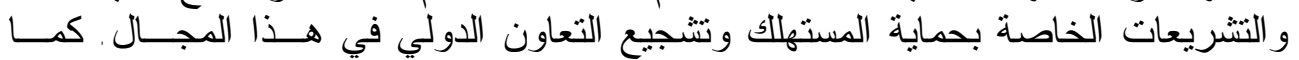

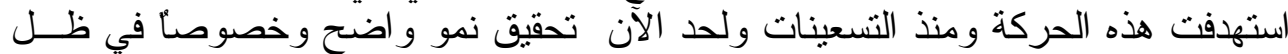
ارتكاب المخالفات بحق المستنهاتلكة.

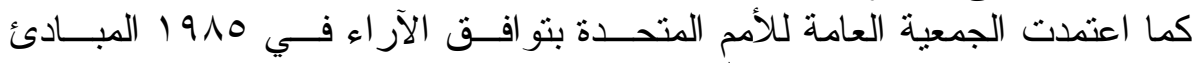

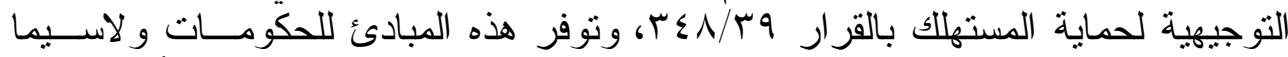

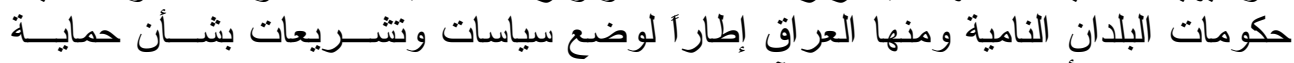

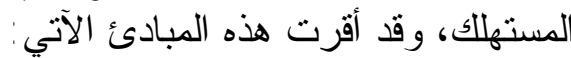
1. الحق في الإعلام (المعرفة).

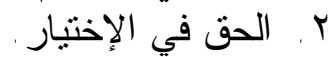
r. آ. الدق في التثقيف. ع. ــ الحق في الإستماع الى آرائه. ه. الحق في الحصول على السلع و الخدمات الضرورية.

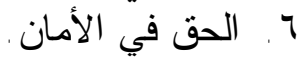

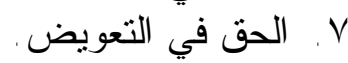

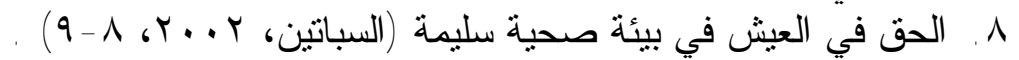

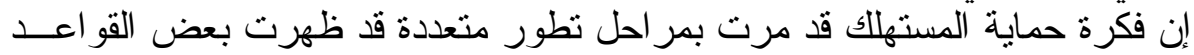

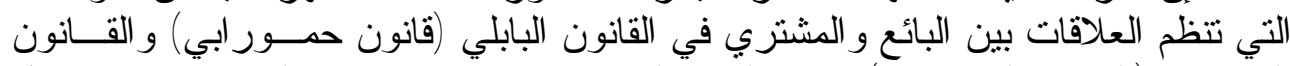

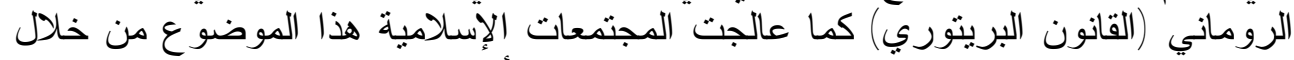

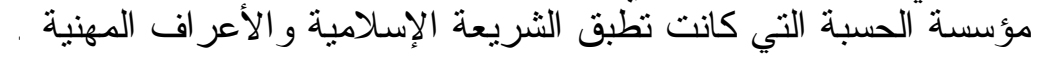


ثانياً - المفهوم التسويقي والحركة الاستهلاكية

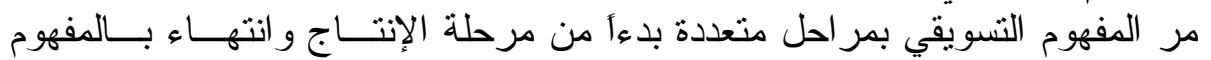

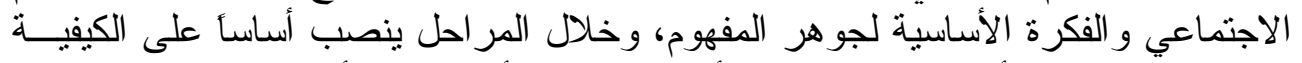

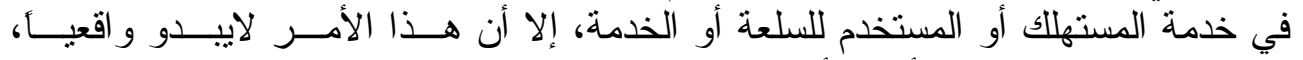
و لآيخرج عن تصور ات و أقو ال أمام الممارسات اللاخلاقفية والظو الهر السلبية التي تظهرها

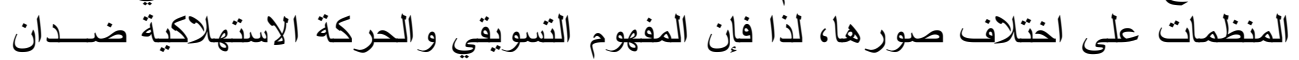

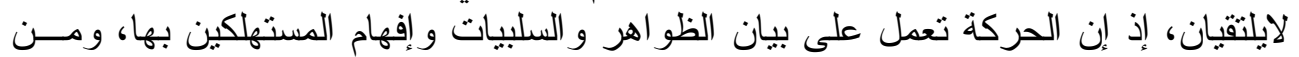
ثم إيصال الثكاوى إلى الجهات العليا للعمل على الحد منهان أو الو معالجتها بطريقة ما (الديوه

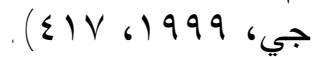

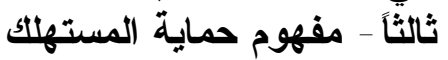

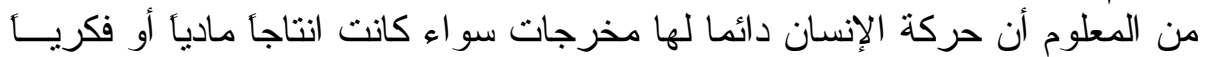

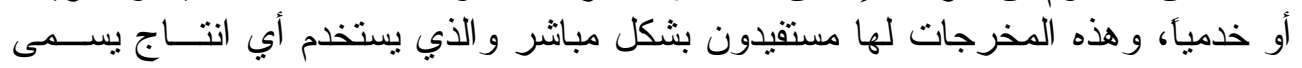

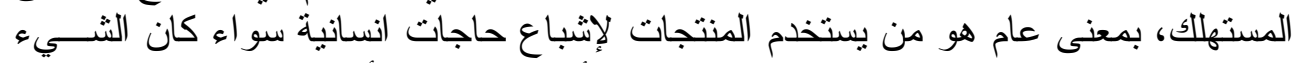

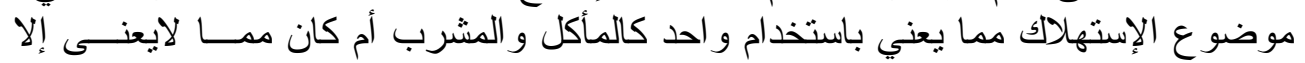

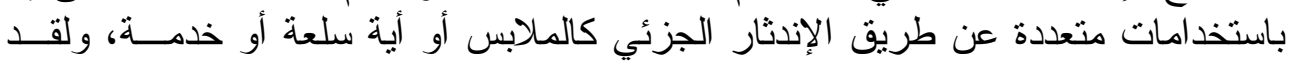

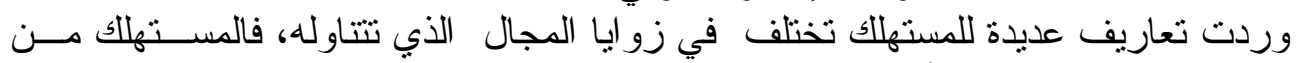

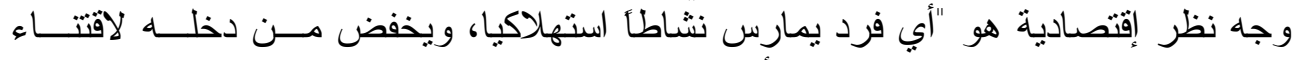

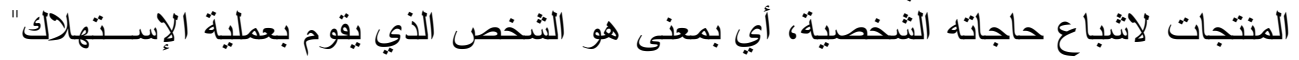

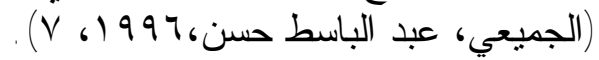

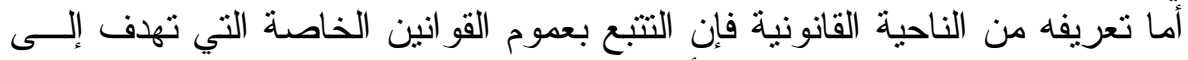

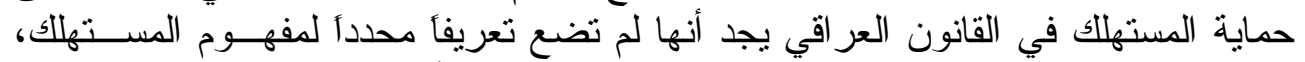

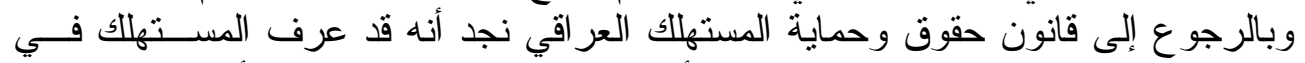

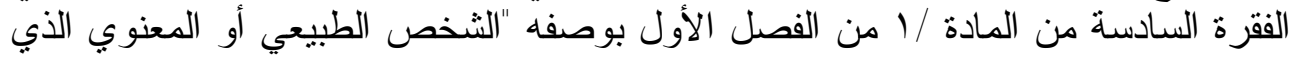

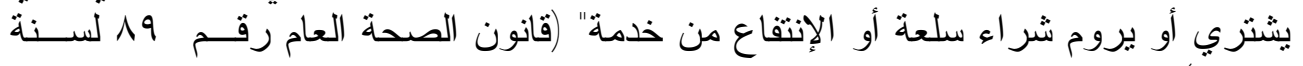
. (191)

ويعرف من الناحية الإجتماعية على أنه "كل فرد في المجتمع بسعى لإثنباع حاجاته

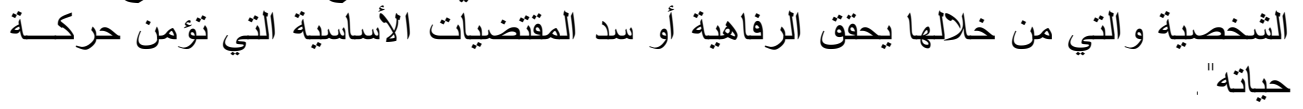
ويعرف من وجهة نظر تسويقية بأنه كل "إنسان يسعى إلى الحصول على متطلباتسهـ

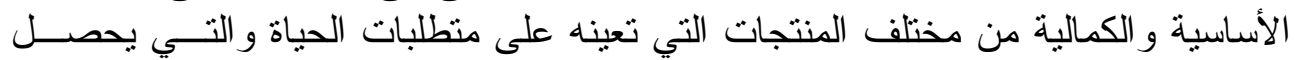
عليها من الأسواق على أساس التعامل مع التجار و وأصحاب المهن المناب المختلفة" (موسى، كمال

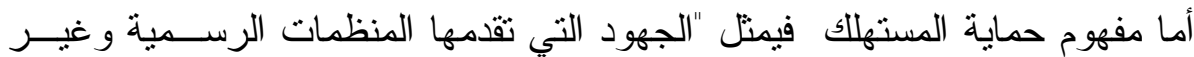

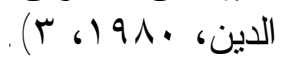

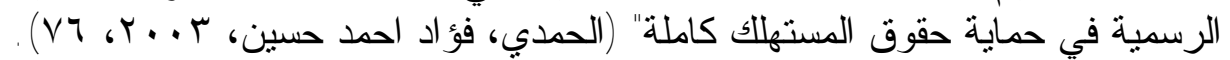

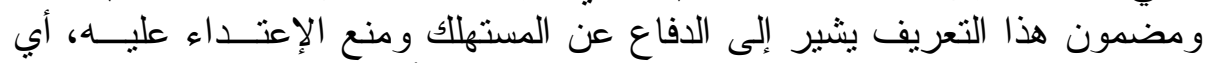

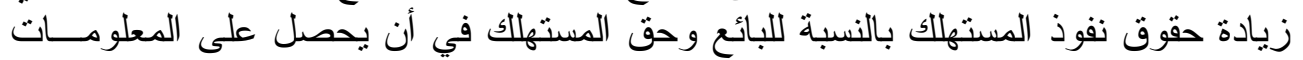

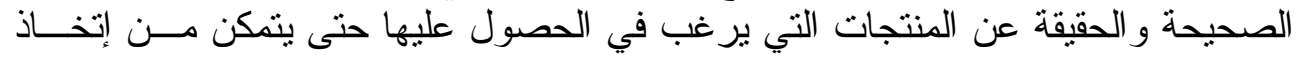

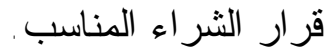




\section{[1.0]}

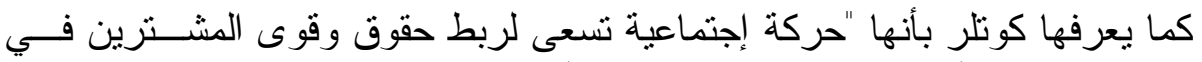

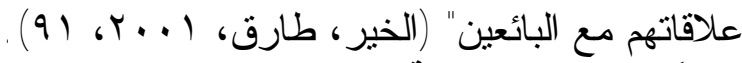

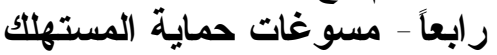

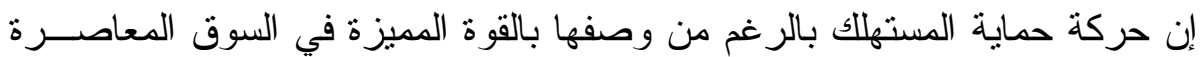

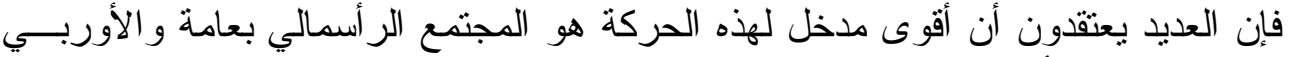

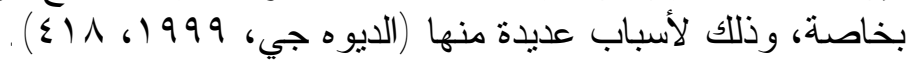

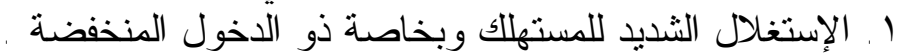

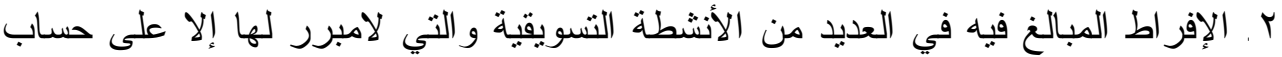

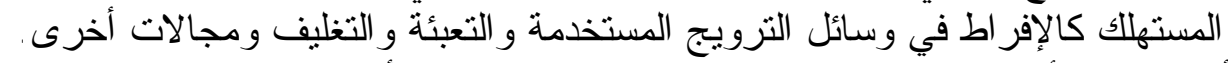

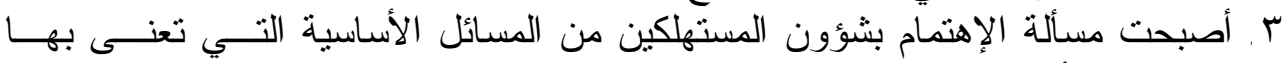

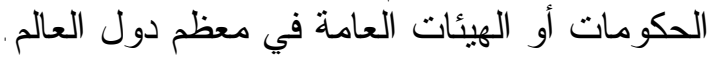

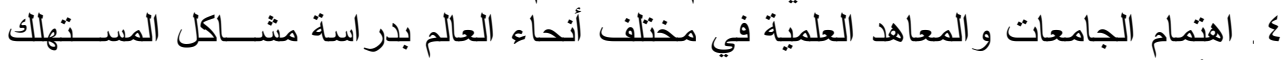

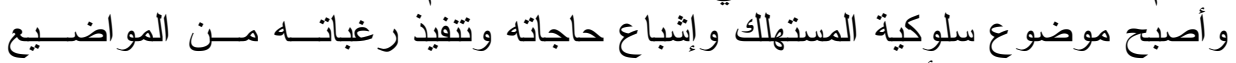

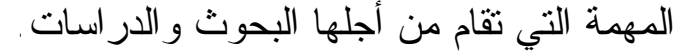
أما من وجهة النظر القانونية فإن حركة حماية المستهلك كثئ كثيرة منها:

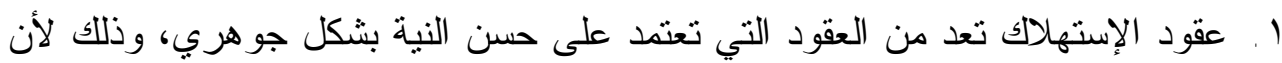

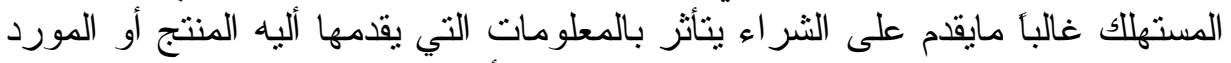

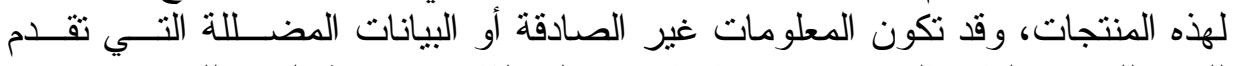

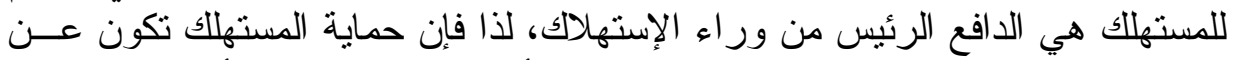

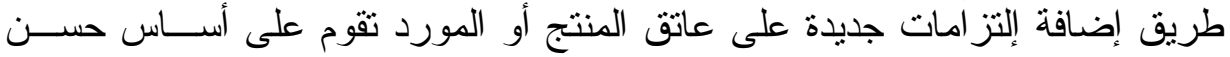

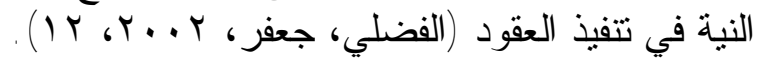

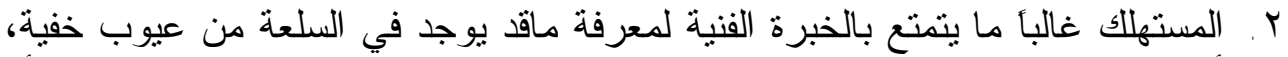

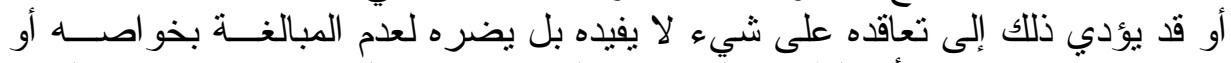

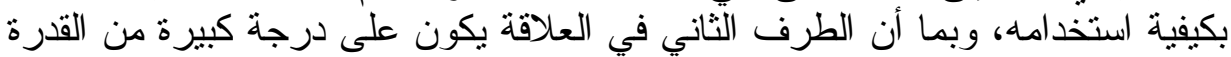

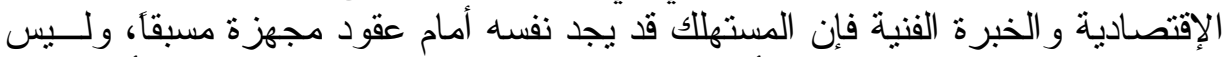

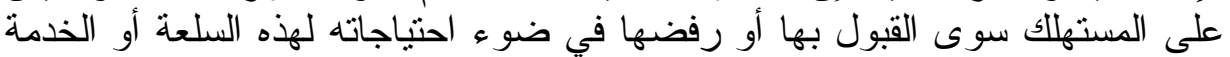

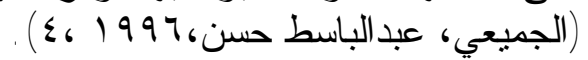

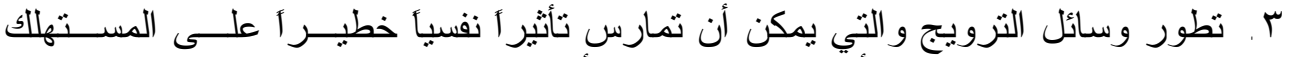

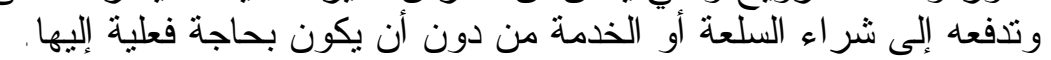

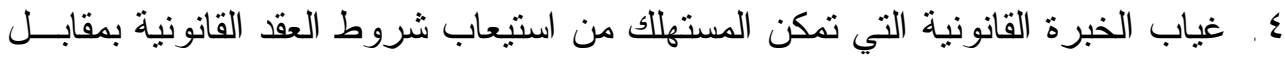

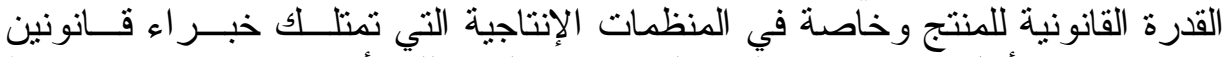

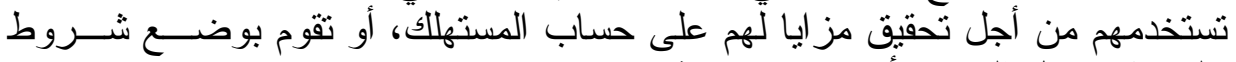
بالعقد قد تصل الى حد أن تكون تعنفية.

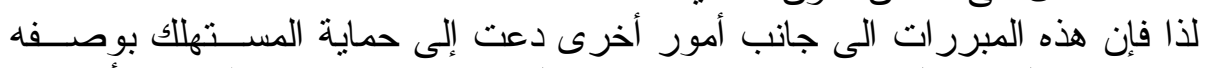

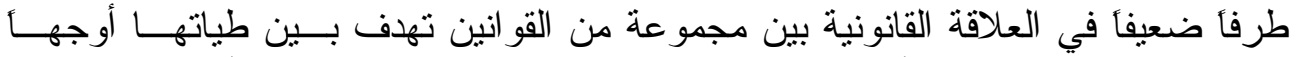

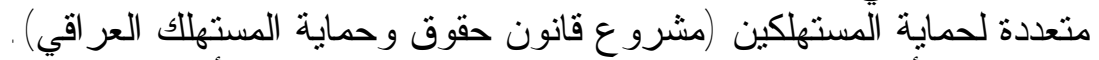

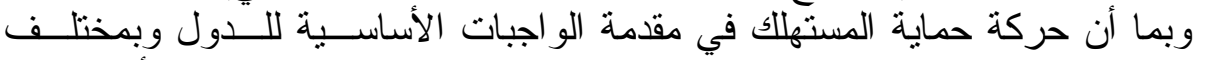

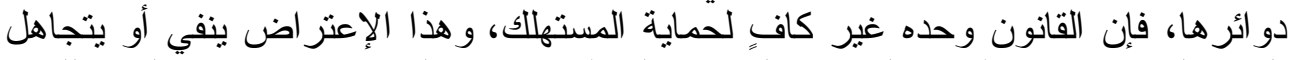
الدور الذي تؤديه منظمات المجتمع الددني و المنظمات غير الرسمية في حماية المستهلك. 


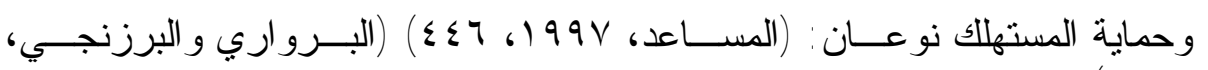

النوع الأول: حماية المستهلك من نفسه نتيجة استخدام مادة معينة مع إدر اكه التام بالضرر

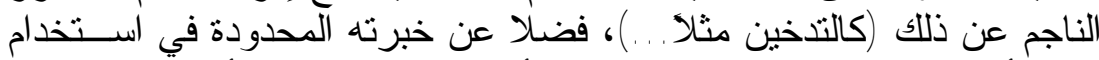

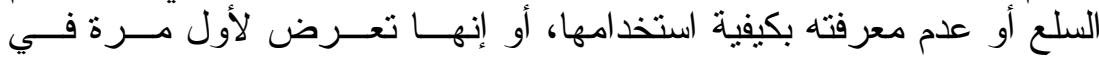

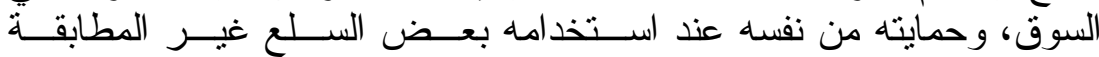

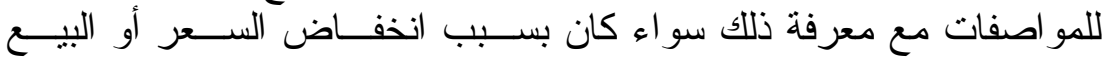

بالتقسيط.

النوع الثاني: حماية المستهلك من غيره ويتعلق بحماية المستهرلك من الغش و الخداع مــنـن

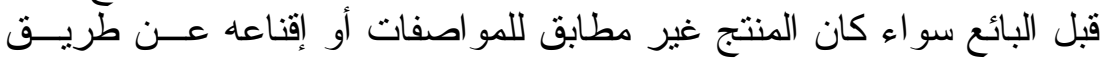

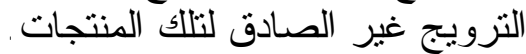

\section{خامساً - أهداف حركة حماية المسترهلئك}

تتباين أهداف حركة حماية المستهلك تبعاً لتباين تتظيمات المستهلكين، ولكن هنـاك

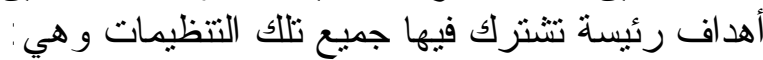

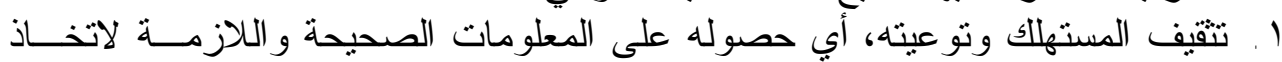

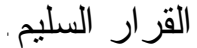

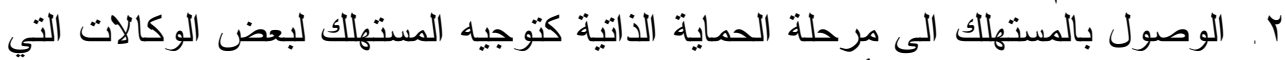

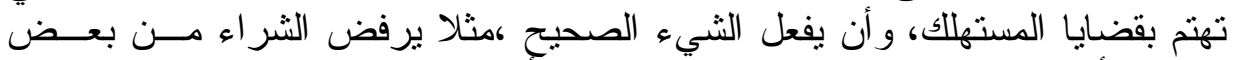

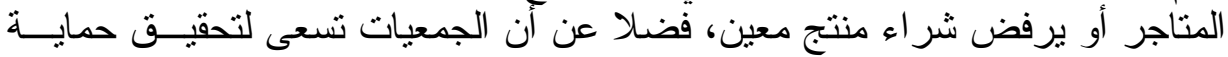
المستهلك ذاتيا من خلال دعمها لقو انين معينة تؤثز في سلوك المين المستهلكين.

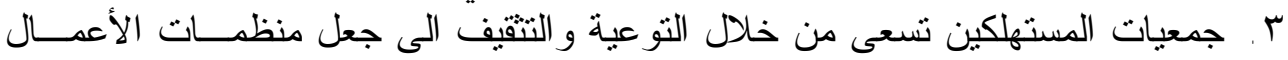

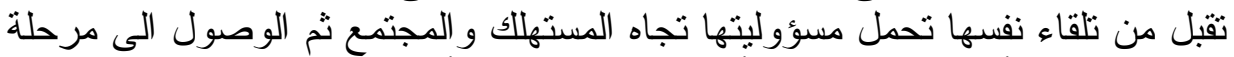

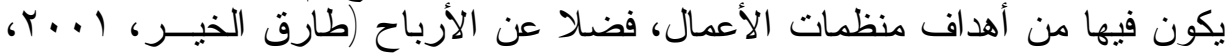
. $97-97$

\section{سادساً - حقوق المستهلك وواجباته}

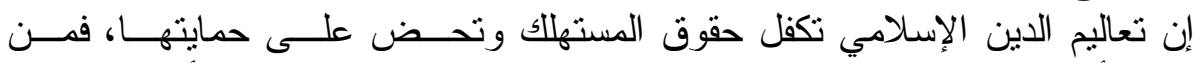

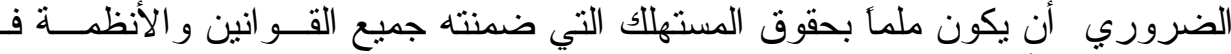

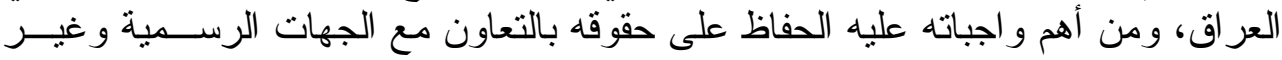

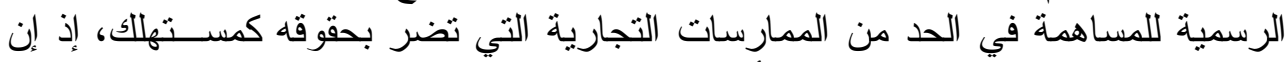
إدر اكه لحقوقه ومسؤولياته هو حجر أساس في حماية حقوقه . لإسات

أ. واجبات المستهلك

أ. التأكد من مصدر السلع بقر اءة البيانات الخاصة بمصدر التجهيز .

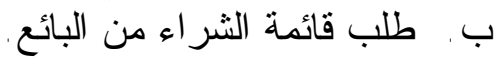

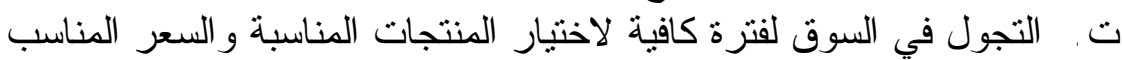
ث. عدم الإنسياق ور اء الإعلانات الكاذبة عن المنتجات.

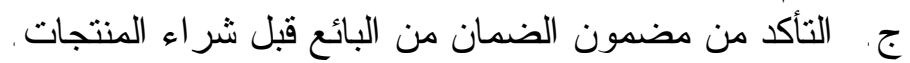

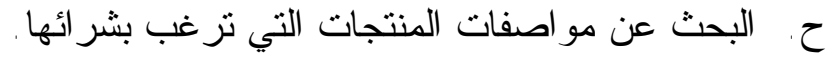

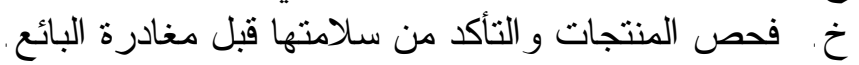

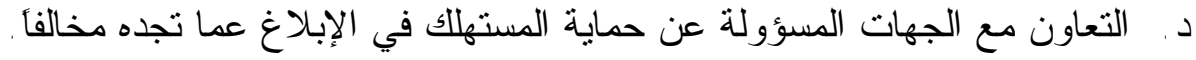


أ. حق الأمان: للمستهلك الحق في الحماية من المنتجات وعمليات الإتتاج والخــدمات

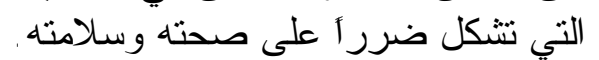

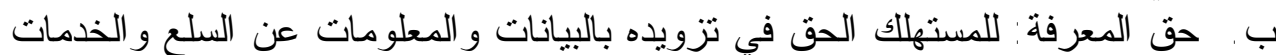

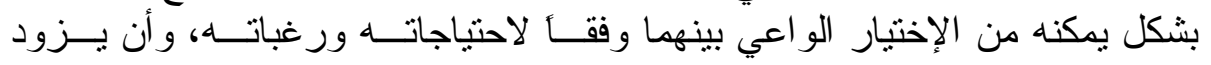

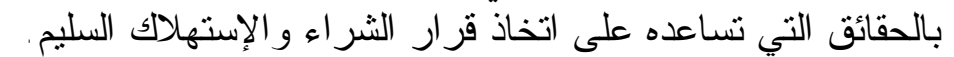

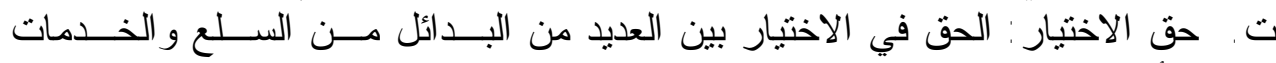

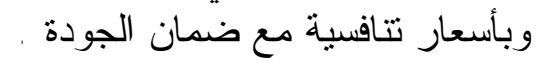

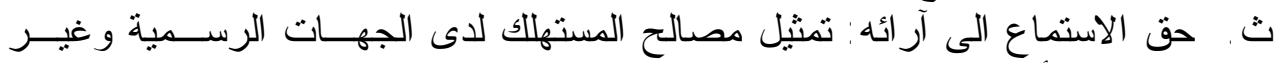

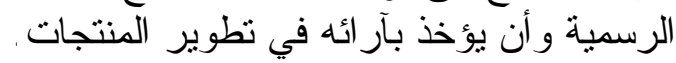

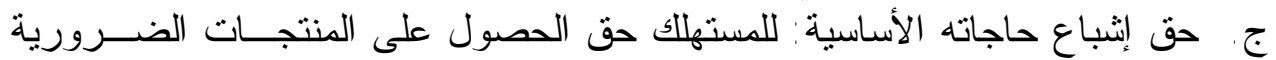

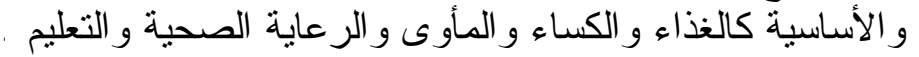

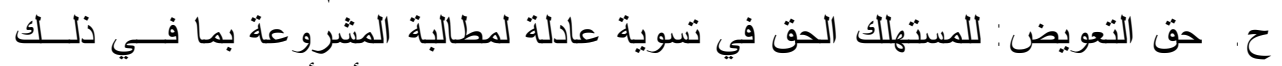

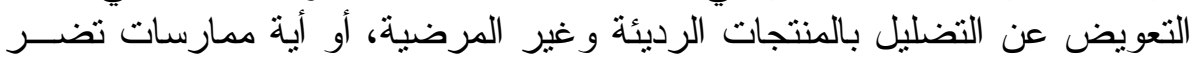
بالمسترهلك.

خ. حق التتقيف: للمستهلك الحق في اكتساب المعارف و المهار ات المطلوبة لممارســـة

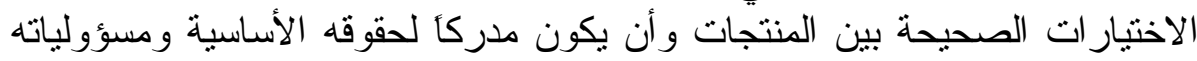

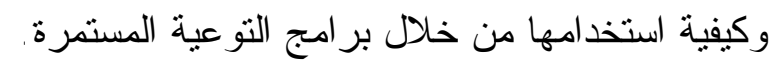

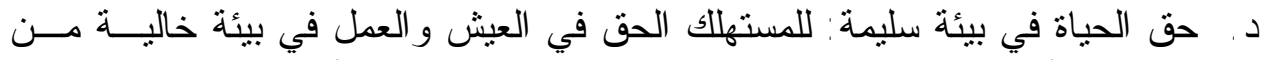

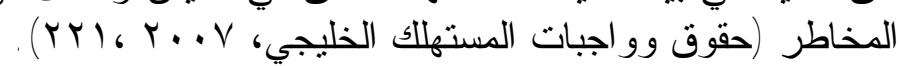
سابعاً - مفهوم حماية المستهلك في المنظور الاستلامي

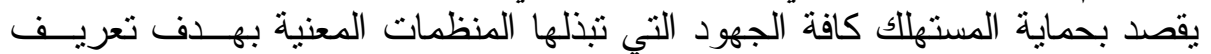

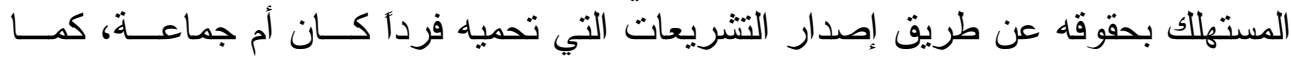

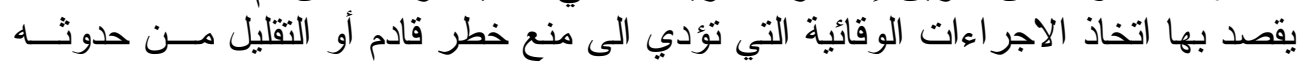

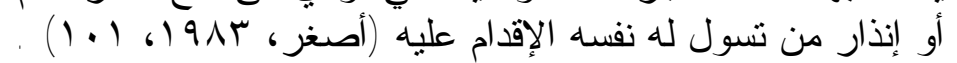

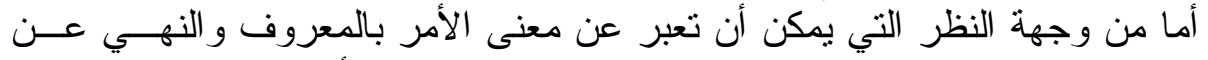

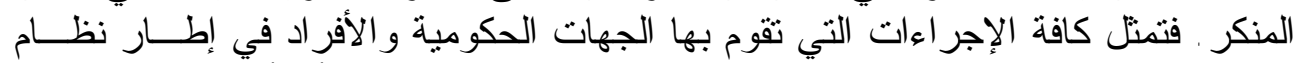

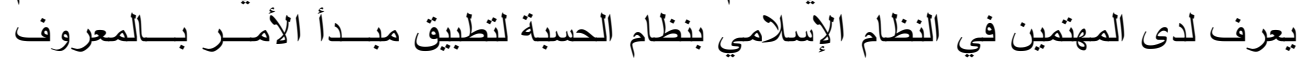

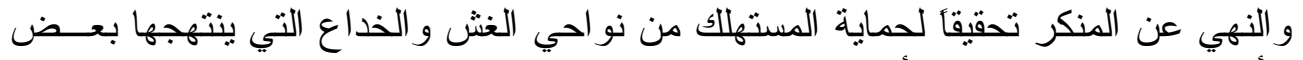

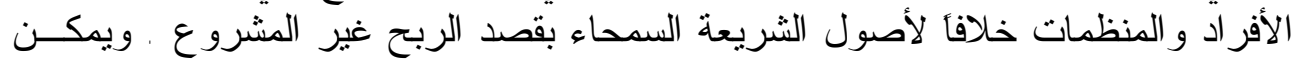

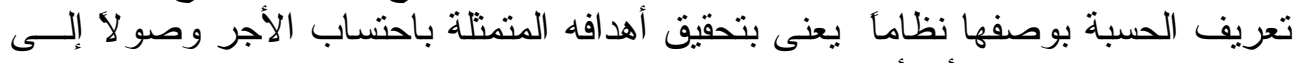

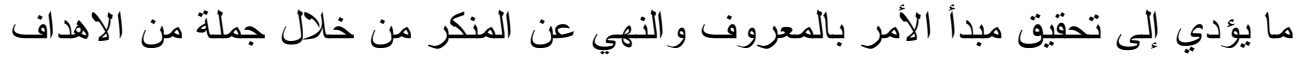

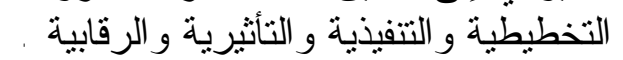

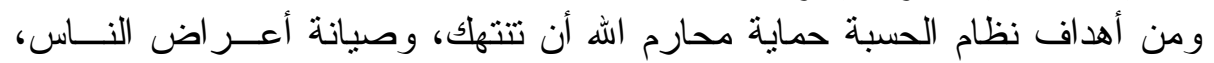

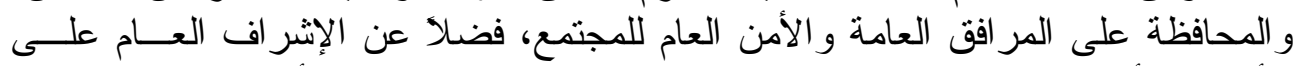

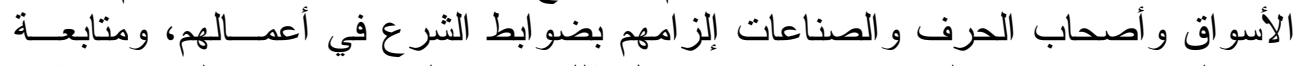

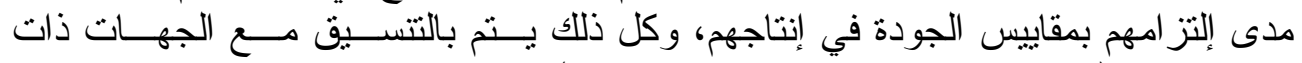

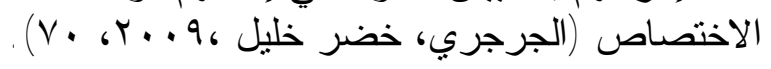




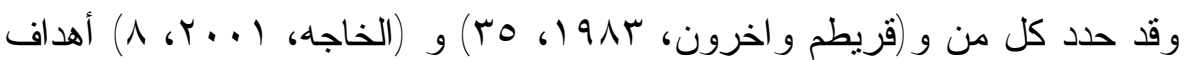

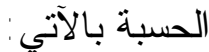

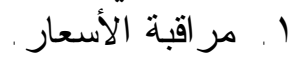

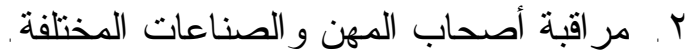

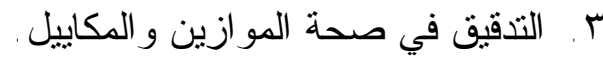
ع . المحاسبة في حالة ثبوت نو احي الغش لاع الدى أصحاب المهنة. 0. الحث على أتباع أحسن الطر ائق الفنية في الإنتاج. وتحقيقا لهذه الأهداف يمارس جهاز الحسبة جملة من النشاطات المختلفة التي يمكن

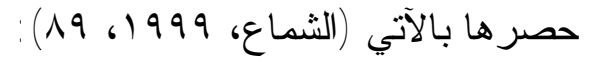
ا ـ التخطبط بمجال عمليات إنتاج المنتجات وعمليات البيع و الثراء اء في السوق الإسلامية

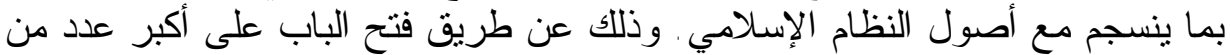

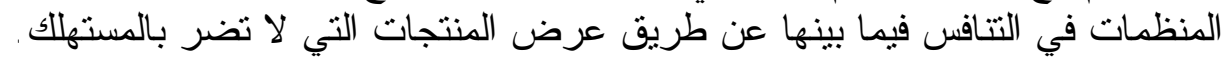

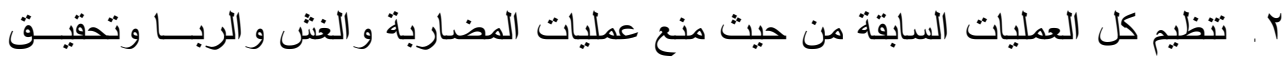
تكافؤ الفرص بين المنظمات.

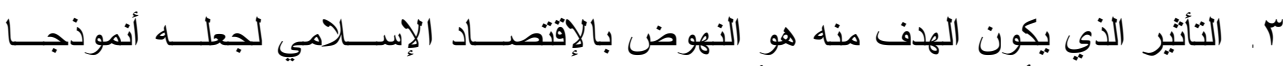

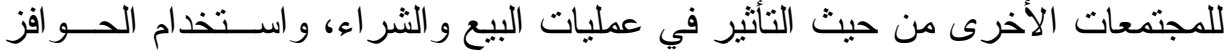

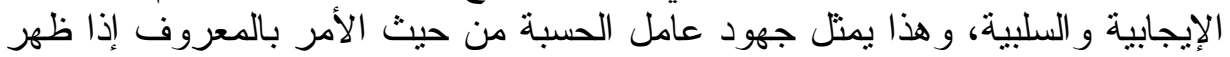

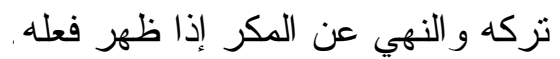

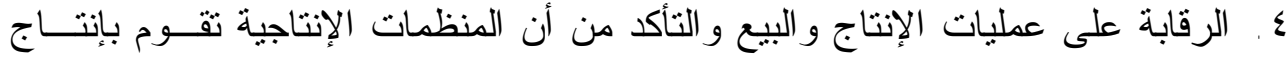

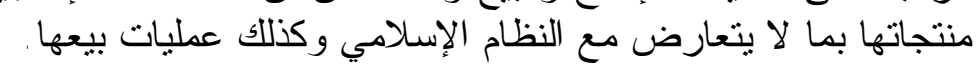

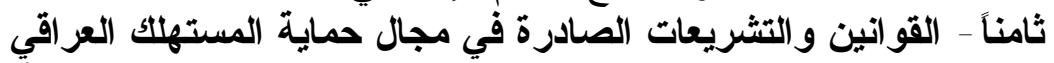

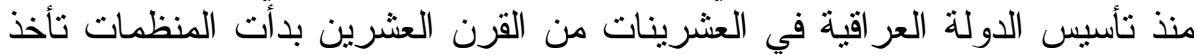

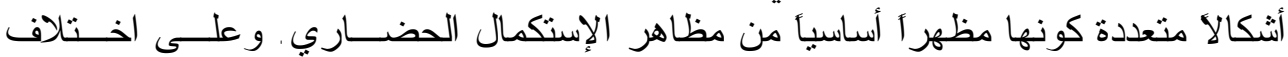

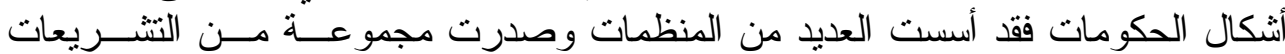

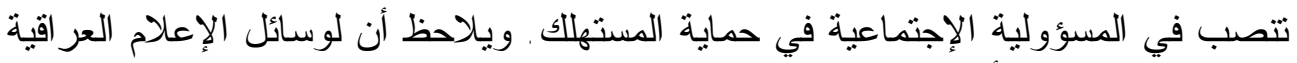

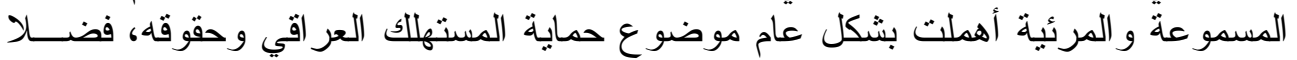

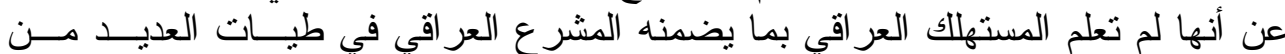

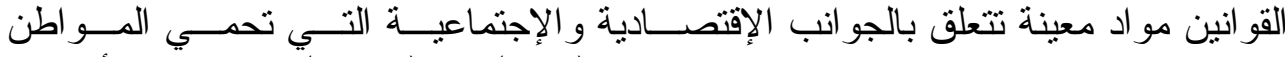

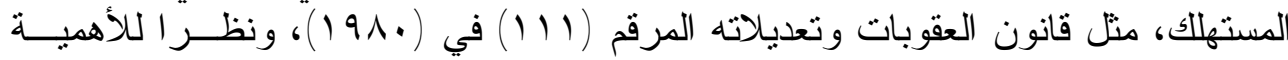

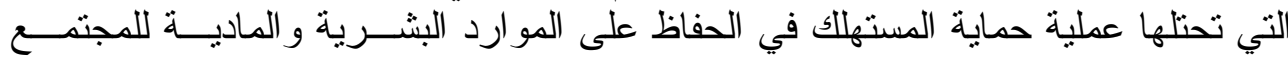

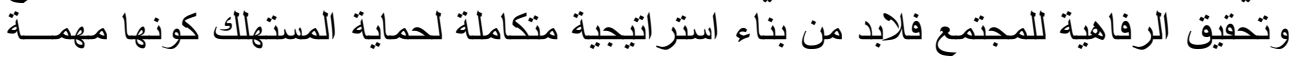
وطنية.

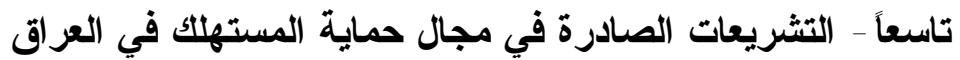

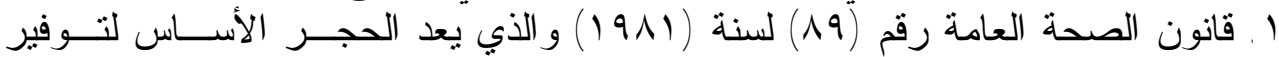
الحماية الصحية للمستهلكين .

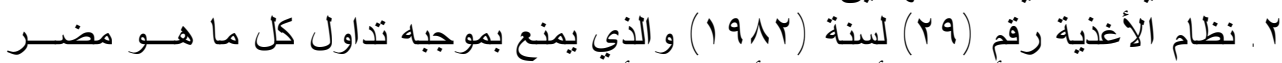

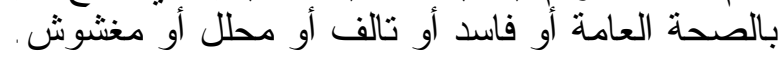

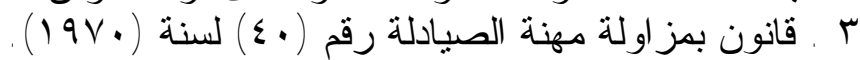




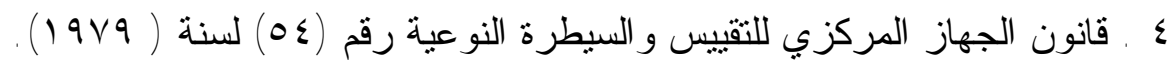

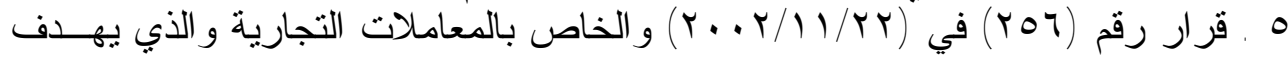

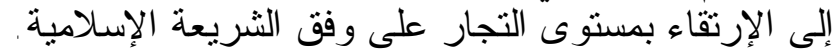

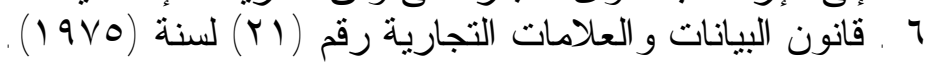

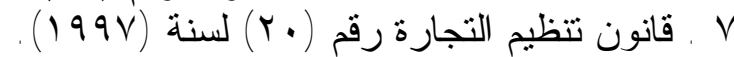

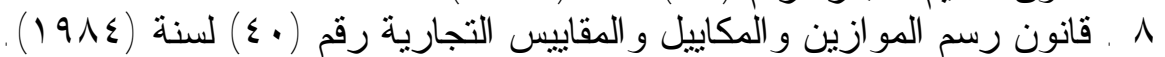

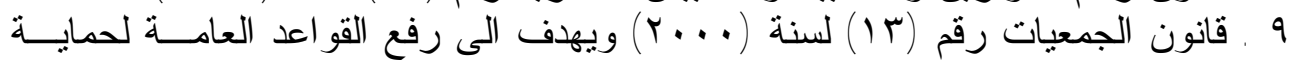

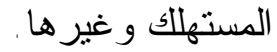

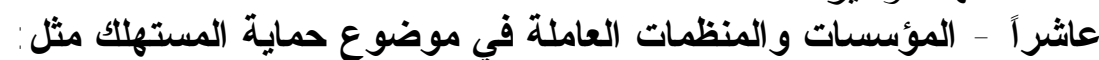

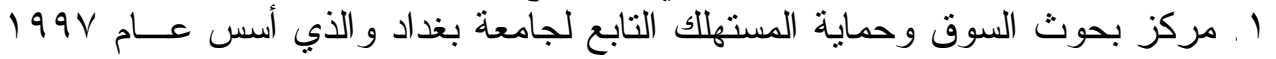

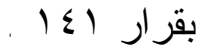

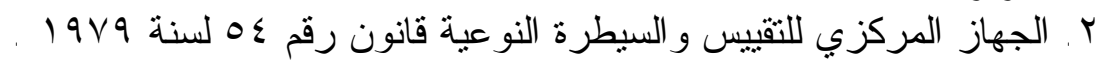

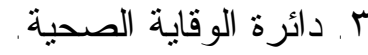

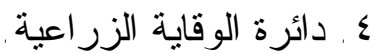

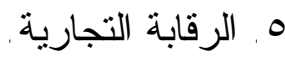

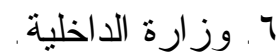

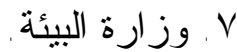

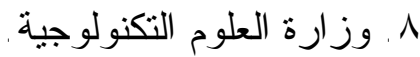

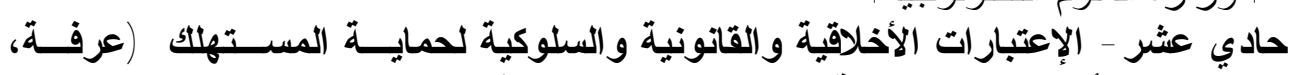

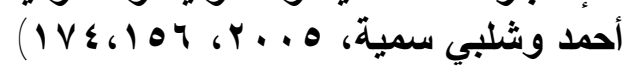

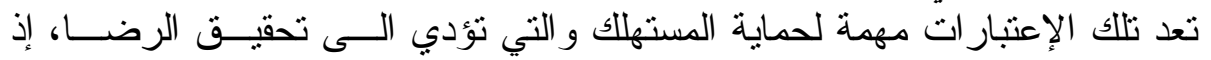

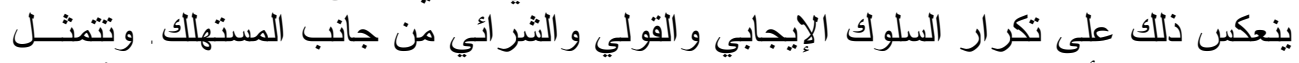

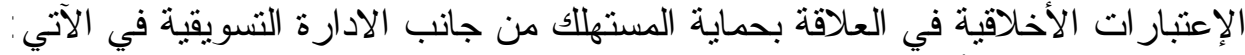

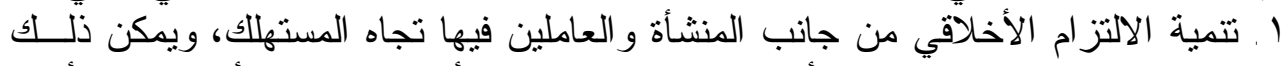

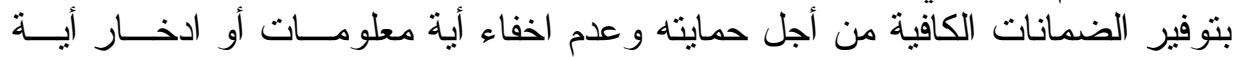

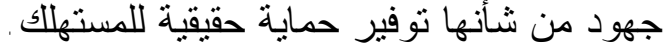

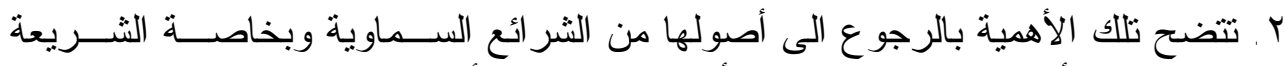

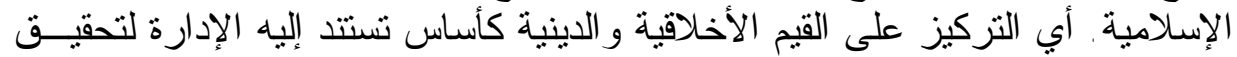

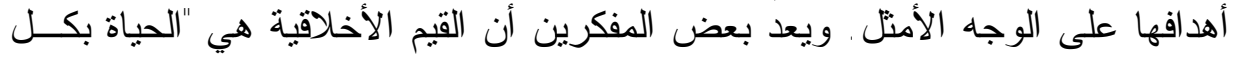

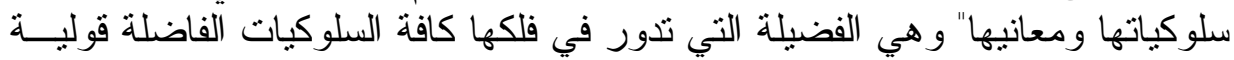

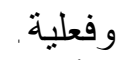

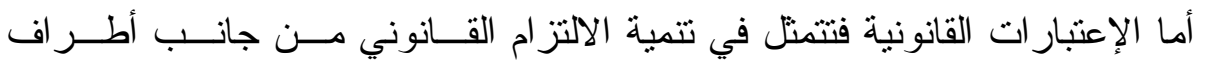

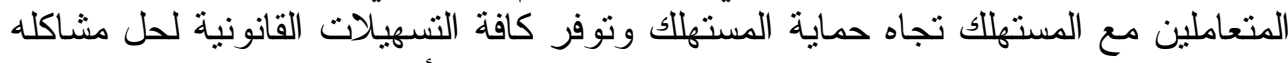

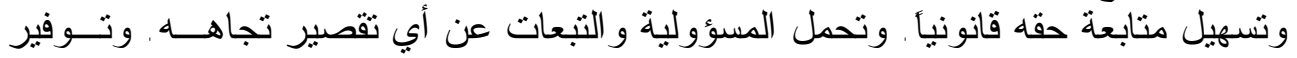

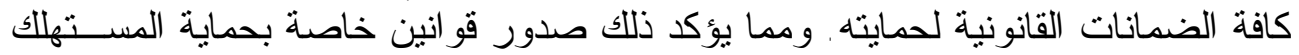

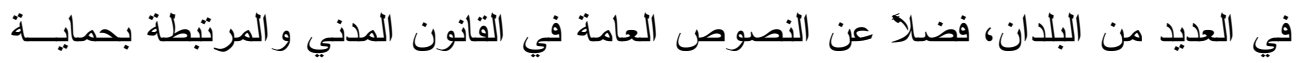

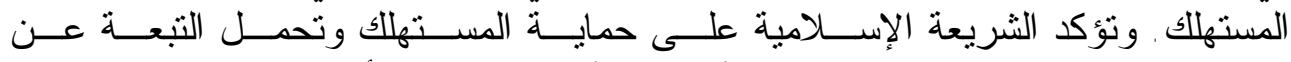
السلع/الخدمات المعيبة في العديد من الآيات القر آنية الكريمة والأحاديث النبوية الثـــريفة، 


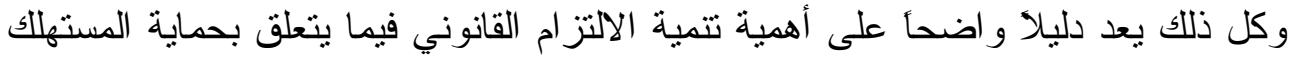

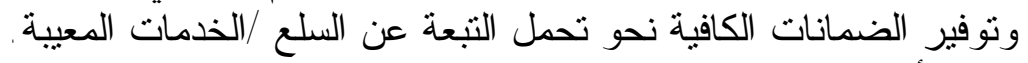

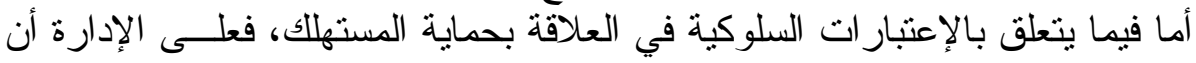

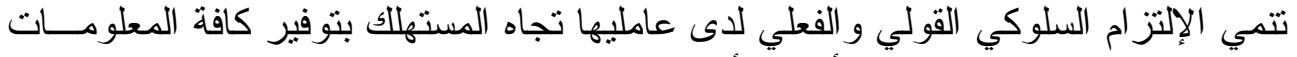

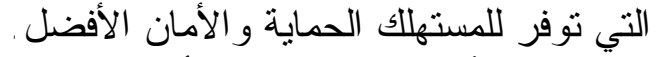

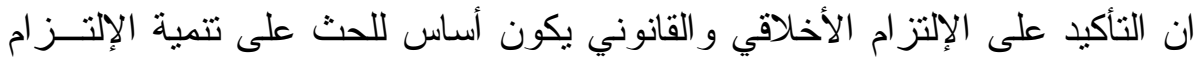

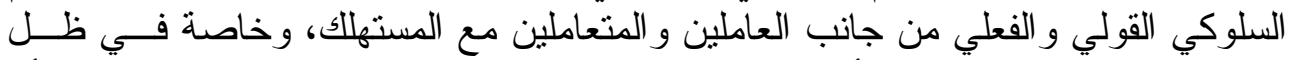

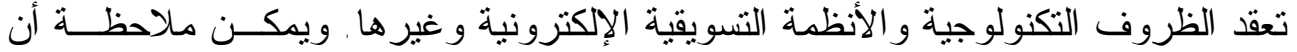

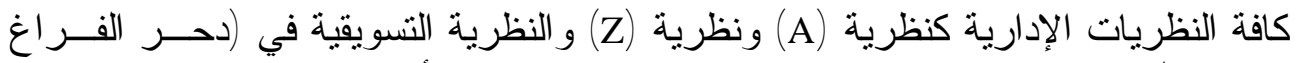

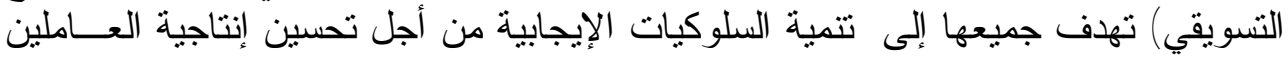

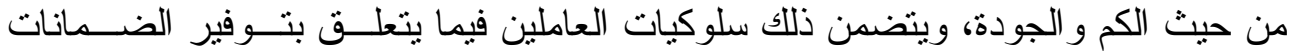
الكافية لحماية المستنهلك.

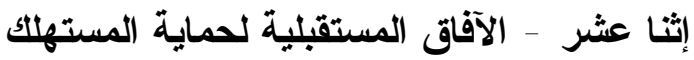

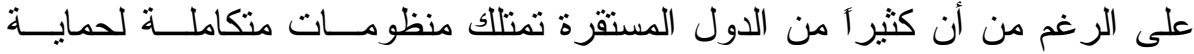

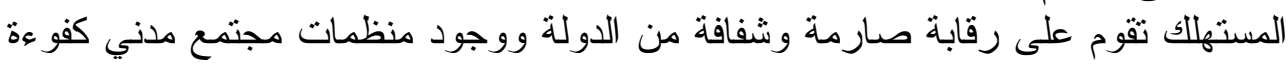

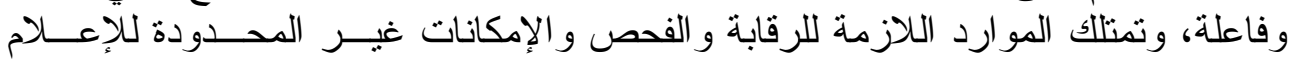

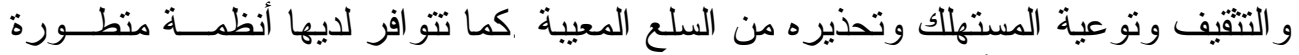

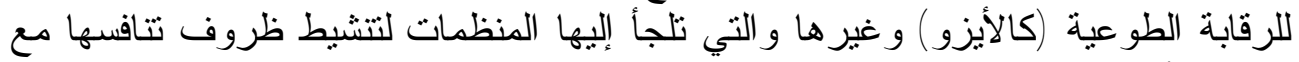

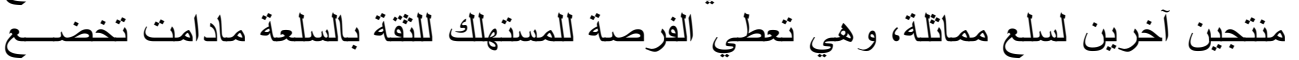
لمعايير الرقابة الإختيارية لهذه الأنظمة المتطورة. نقول رغم كلة كل هذه الضمانات المتوفرة

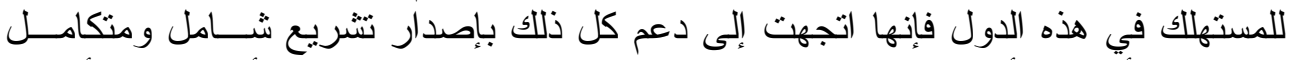

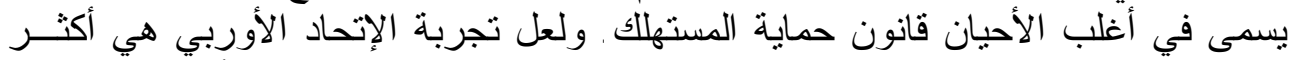

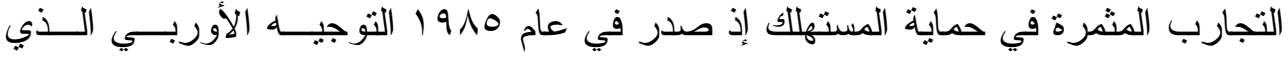

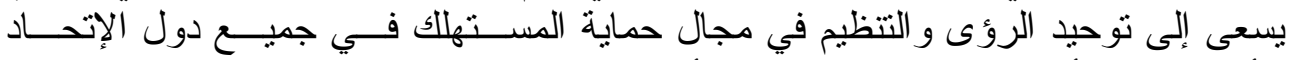

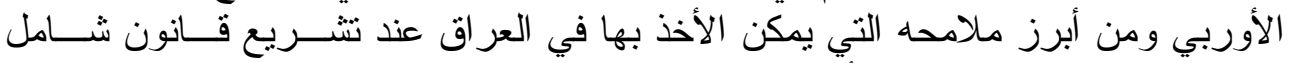

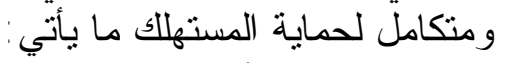

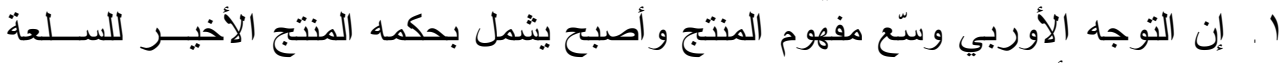

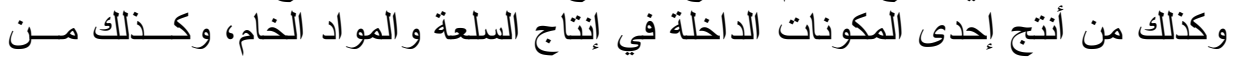

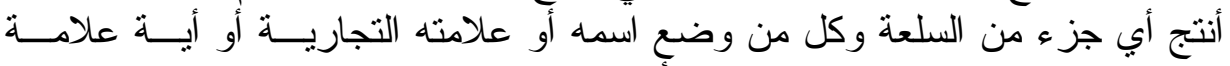

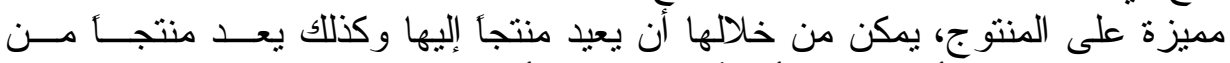

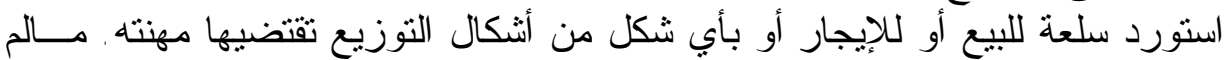

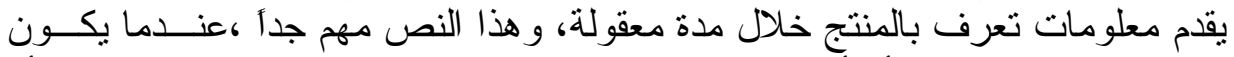

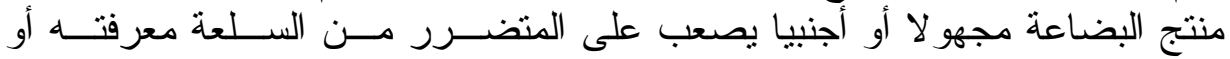

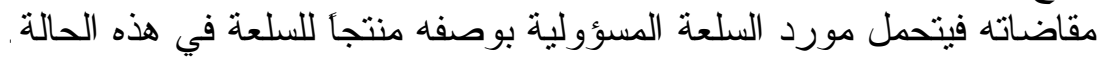

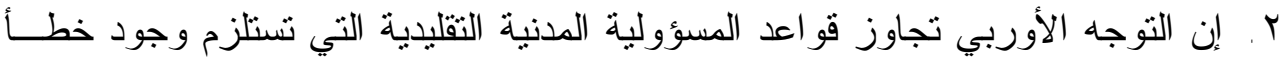

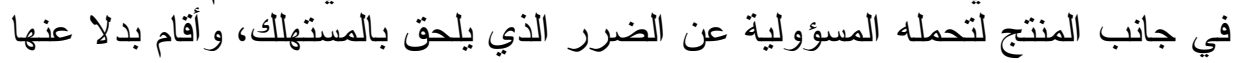

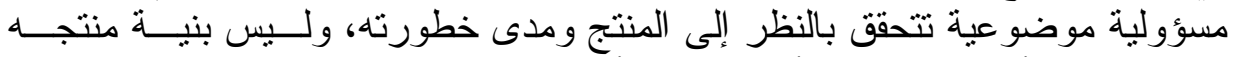

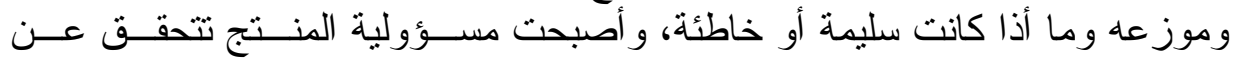




\section{[111] محمد}

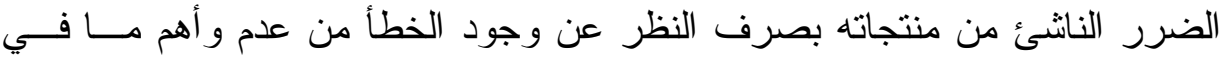

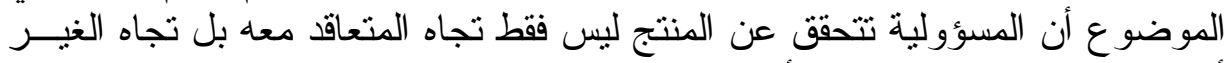

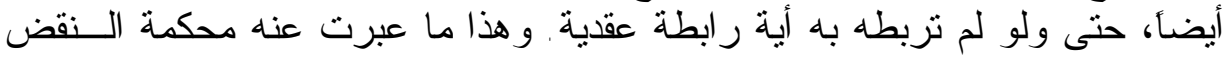

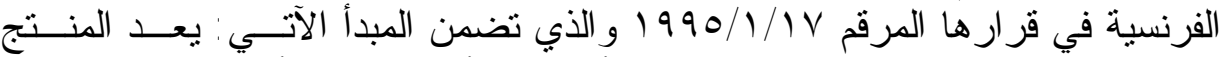

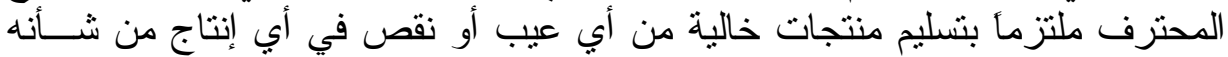

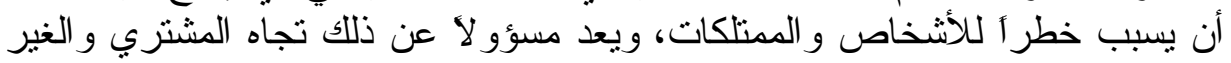

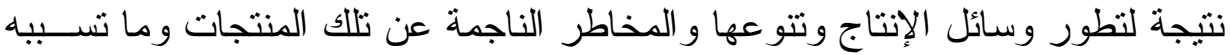

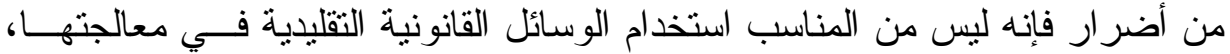

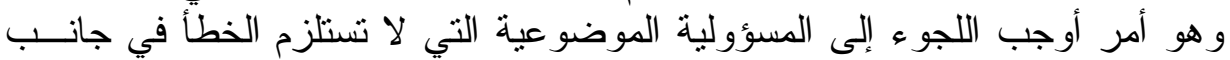

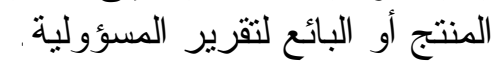

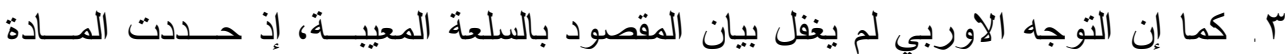

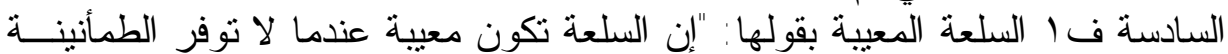

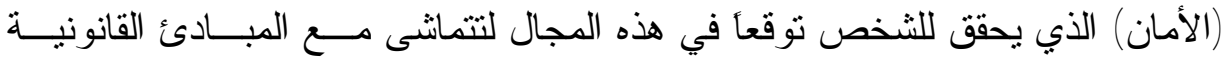

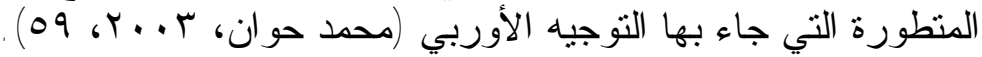

\section{وصف نتائج البحث وتحليلها}

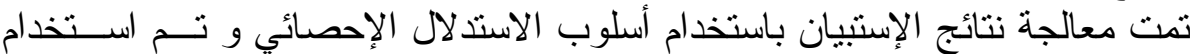

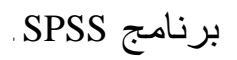

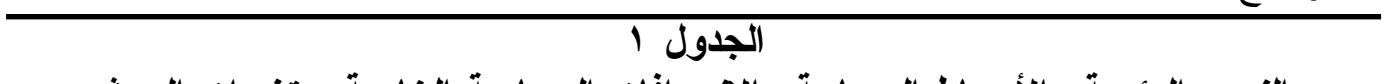

النسب المئوية والأوساط الحسابية والاحر افات المعيارية الخاصة بمتغيرات البحث $\left(\mathbf{X}_{1}-\mathbf{X}_{6}\right)$

\begin{tabular}{|c|c|c|c|c|c|c|c|c|}
\hline Tعنوية T Tحسوبة & المعياري & الحسابي & أبداً & نادراً & الأحيان & الأحيان & دائما & المتغير ات \\
\hline 115.785 & 0.812 & 4.419 & & $\% 3.1$ & $\% 11.5$ & $\% 25.8$ & $\% 59.6$ & $\overline{X_{1}}$ \\
\hline 88.305 & 0.960 & 3.984 & $\% 0.7$ & $\% 7.5$ & $\% 20.3$ & $\% 35.6$ & \%35.8 & $\overline{X_{2}}$ \\
\hline 62.606 & 0.946 & 2.783 & $\% 8.4$ & $\% 28.9$ & $\% 42.4$ & $\% 16.6$ & \%3.6 & $\mathrm{X}_{3}$ \\
\hline 57.042 & 1.255 & 3.372 & $\% 8.8$ & $\% 16.6$ & $\% 26.5$ & $\% 24.1$ & \%23.6 & $\overline{X_{4}}$ \\
\hline 106.257 & 0.870 & 4.344 & $\% 0.7$ & $\% 3.3$ & $\% 2.6$ & $\% 27.8$ & $\% 55.6$ & $\overline{X_{5}}$ \\
\hline 69.125 & 1.067 & 3.466 & $\overline{6}$ & $\% 9.1$ & $\% 34.9$ & $\% 32.7$ & $\% 17.4$ & $\overline{X_{6}}$ \\
\hline
\end{tabular}

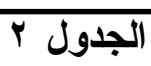

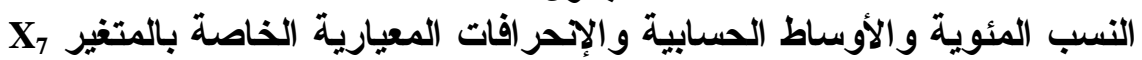

\begin{tabular}{|c|c|c|c|c|c|c|c|c|}
\hline t المحسوبة & المعياري & الوسطب & اخرى & يتصل بجهات & يستخدمها & رد السلعة & رلمئة & المتغيرات \\
\hline 99.44 & 0.927 & 4.55 & $\% 3.8$ & $\% 2.6$ & $\% 4.6$ & $\% 12.2$ & $\% 76.8$ & $\mathrm{x}_{7}$ \\
\hline
\end{tabular}

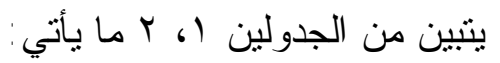




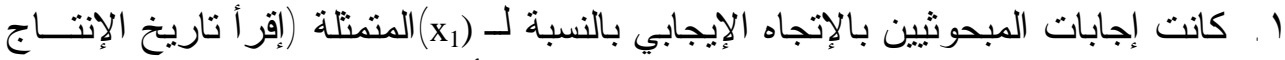

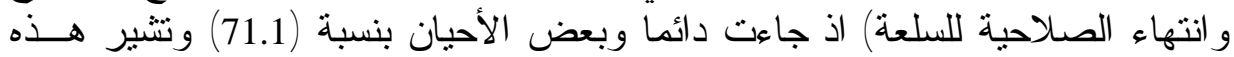

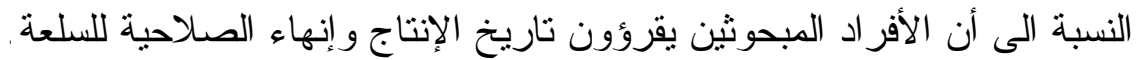

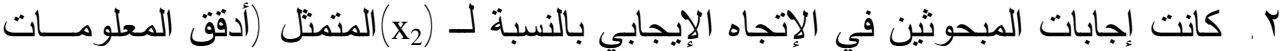

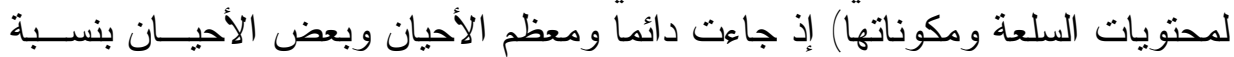

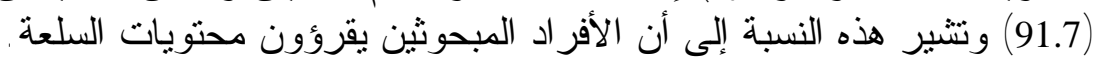

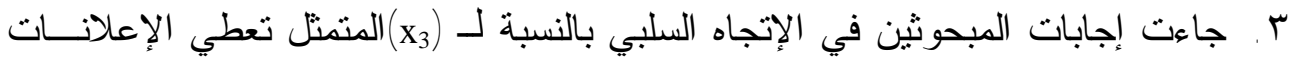

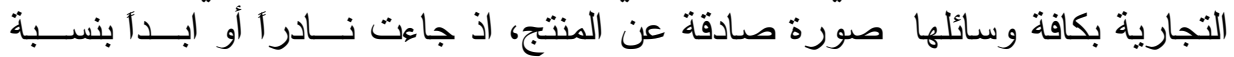

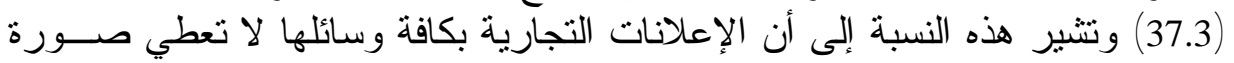
صادقة عن السلعة. ع. كانت إجابات المبحوثين في الإتجاه الإيجابي بالنسبة (x) المتنتل ( يتم التأكد من قبلي الإني حول وزن المنتج المشتزى وحجمه، اذ جاءت دائما وبعض الإن الأحيــان بنســبة (50.1)

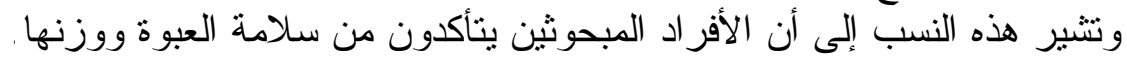

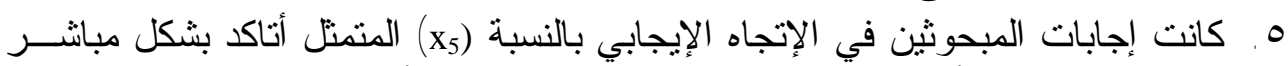

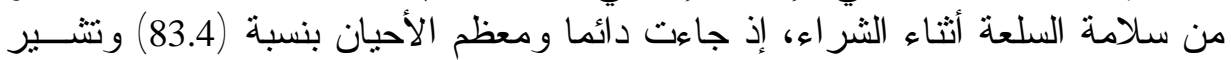

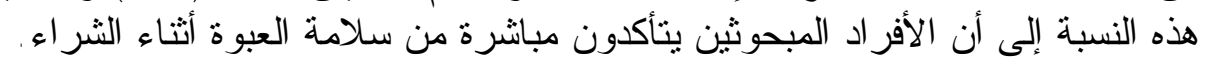

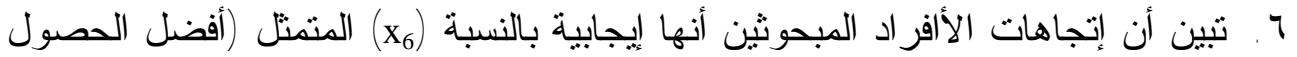

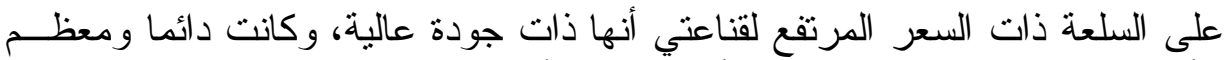

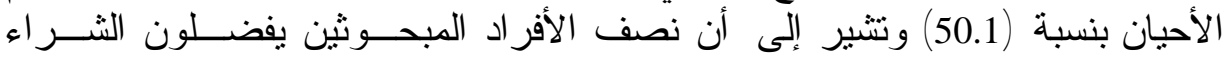
بالسعر المرتفع.

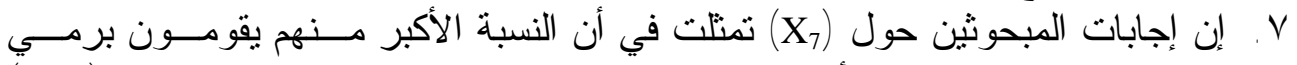

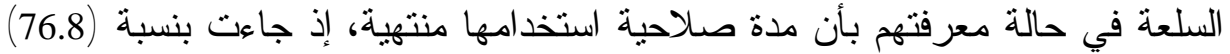

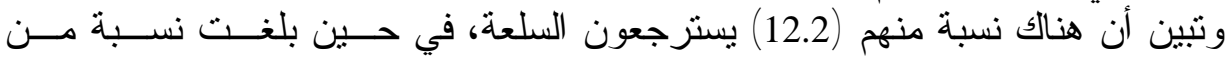

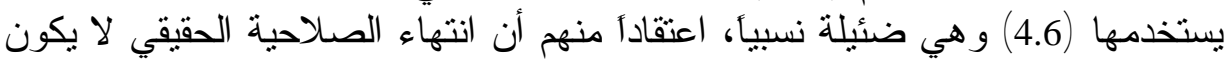

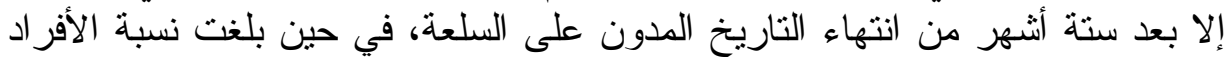

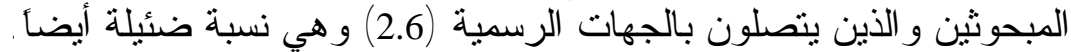

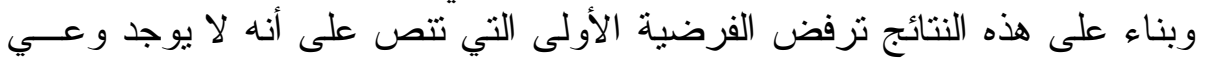

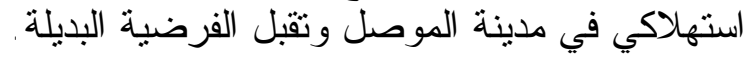

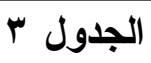

النسب المئوية والأوساط الحسابية والإحر افات المعيارية الخاصة بالمتغير

\begin{tabular}{|c|c|c|c|c|c|c|c|}
\hline انميراف & حسابي & لا لا اتفق & لا اتفق & محايد & اتفق & بثدة & لمتغير \\
\hline 0.927 & 2.65 & 21.4 & 25.8 & 26.7 & 17.9 & 8.2 & $X_{8}$ \\
\hline
\end{tabular}

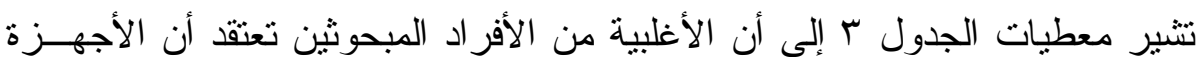

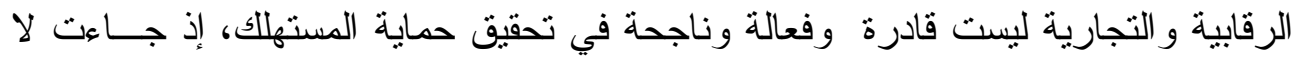




\section{[محد]}

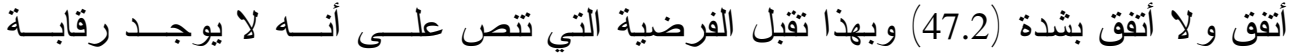

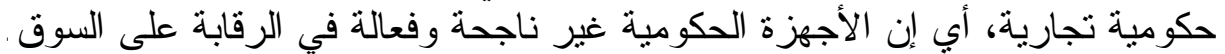

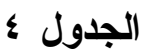

النسب المئوية والأوساط الحسابية والإحر افات المعيارية الخاصة بمتغيرات البحث(X-X)

\begin{tabular}{|c|c|c|c|c|c|c|}
\hline T المحسوبة & الإعباري & الحسابط & المجموع & ل & نعم & المتغيرات \\
\hline 49.658 & 0.467 & 1.322 & $\% 100$ & $\% 67.8$ & $\% 32.2$ & $\mathrm{X}_{9}$ \\
\hline 49.821 & 0.471 & 1.331 & $\% 100$ & $\% 66.9$ & $\% 33.1$ & $\mathrm{X}_{10}$ \\
\hline 50.227 & 0.4832 & 1.369 & $\% 100$ & $\% 62.9$ & \%39.9 & $X_{11}$ \\
\hline 46.073 & 0.302 & 1.898 & $\% 100$ & $\% 10.2$ & $\% 89.8$ & $X_{12}$ \\
\hline
\end{tabular}

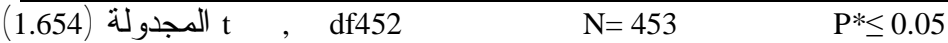

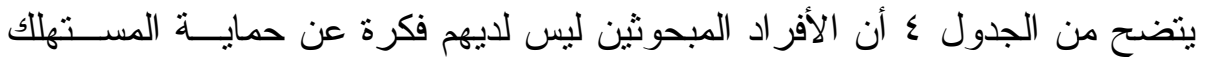

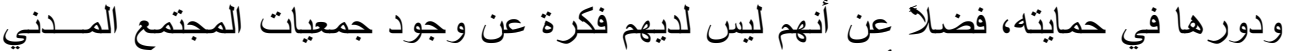

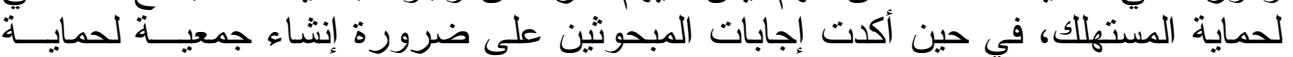
المستهلك في مدينة ألموصل حين الماءت نسبة الإتقاق (89.9) .

\section{- الجدول}

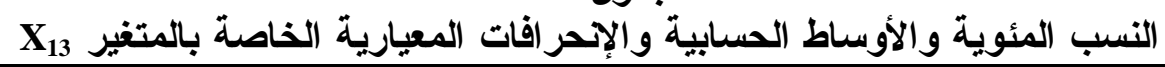

\begin{tabular}{|c|c|c|c|c|}
\hline المعياري & اللوسط الحسابي & معا & مساندة الجهات الرسمية الرقابة & نشر الوعي \\
\hline 0.405 & 1.792 & $\% 20.8$ & & $\% 79.2$ \\
\hline
\end{tabular}

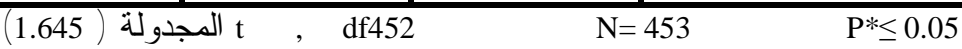

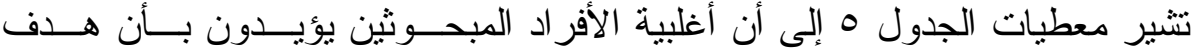

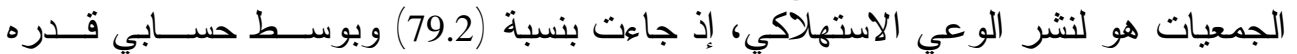

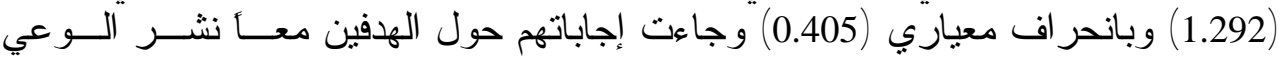

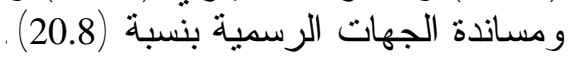

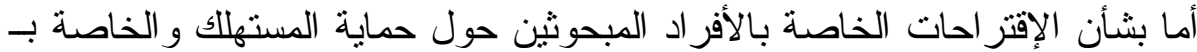
Sانت على النحو الآتي:

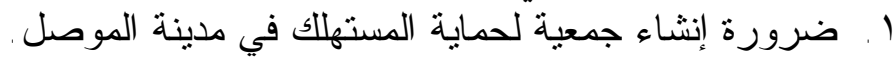

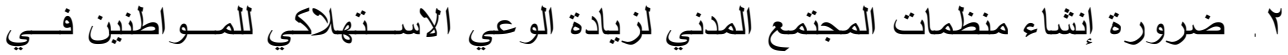
مدينة الموصل. r. . ضرورة تفعيل وحدة جهاز التقييس و السيطرة النوعية، وذللك باعتماد معـايير دوليــة

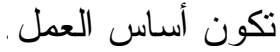
ع . ضرورة الرقابة المستمرة على السوق العر اقية (مدينة الموصل) .

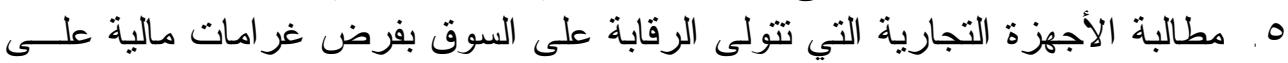

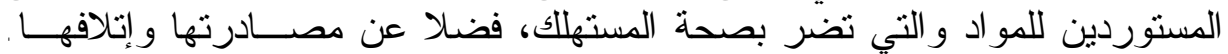
وتفعيل الدور الرقابي للأجهزة التجارية لمر اقبة المو اد التي تدخل البلد . 
7 . . ضرورة وجود تتسيق وتعاون بين الجمعيات الخاصة بحماية المسـتـهلك ومنظمــات

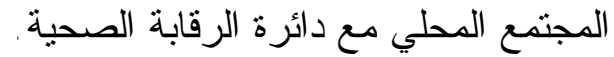

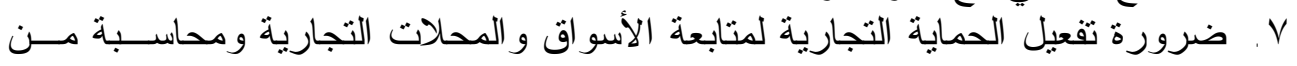

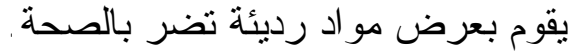

الإستنتاجات و المقترحات

$$
\text { أولاً - الإستنتاجات ولمتات }
$$

ا ـ. من مناقثتة النتائج التي تبين أن الأفر اد المبحوثين يقرؤون تـاريخ ومـــة صــلاحية

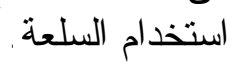

r r تبين من إجابات المبحوثين أنه لا يوجد رقابة فاعلة وناجحة لتحقيق حماية المستهلك.

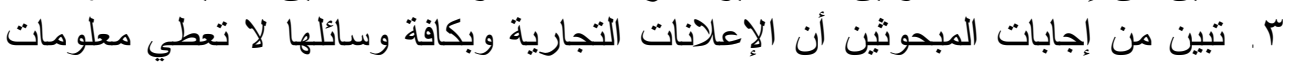
عادقة عن السلعة.

ع ـ كثفت نتائج البحث على أن الأفر اد المبحوثين يتأكدون من سلامة العبوة ووزنها.

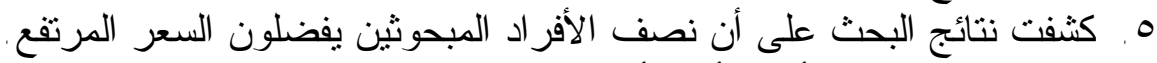

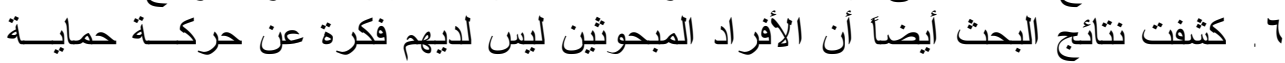

$$
\text { المستهلك ودور ها في حمايته. }
$$

بناء على الدر اسة النظرية و الميدانية ونتائج الإنــنبيان ومناقثــتها يمكنتـا تقــيم

ثانياً - المقترحات

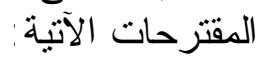

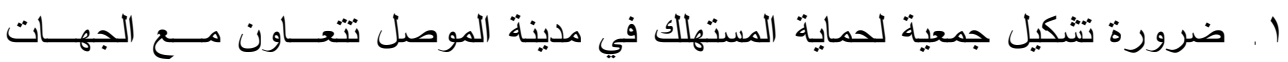

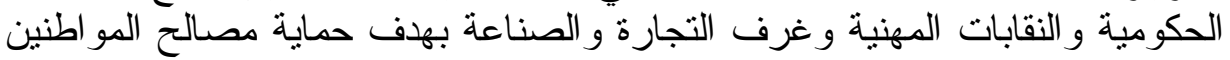

$$
\text { ورفع من مستوى و عيهم الإستهلاكي. }
$$

r r. عمل برامج تثقفية وإرشادية و إعلامية نسهم في تعزيز قدرة المستهلكين على اختبار السلع وكيفية استخدامها.

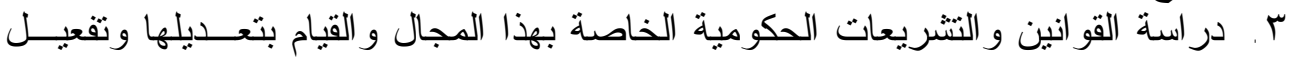

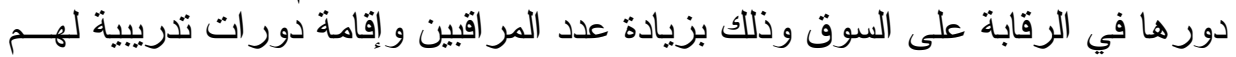

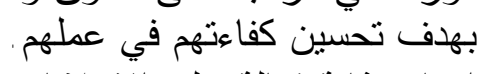

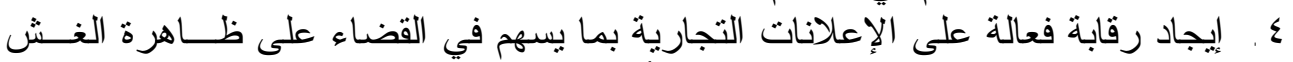

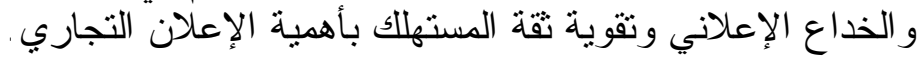

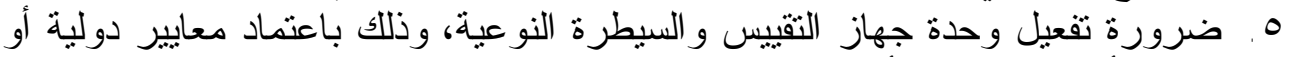
قطرية أو محلية تكون أساسأ للعمل. فيلون

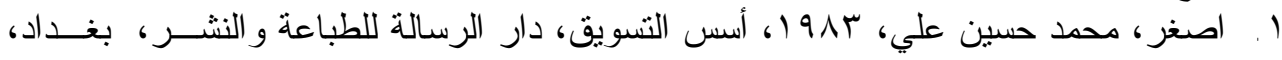

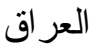

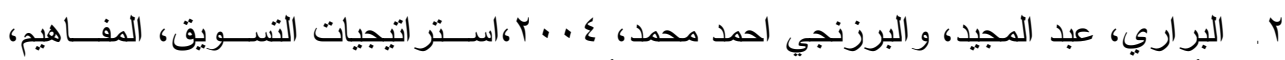
الأسس، الوظائف، دار و وائل نشر و التوزيع، الأردن.

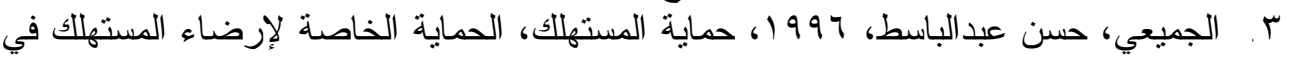
عقود الآستهلاك، دار النهظة العربية، القاهرة. 


\section{[110] محمد}

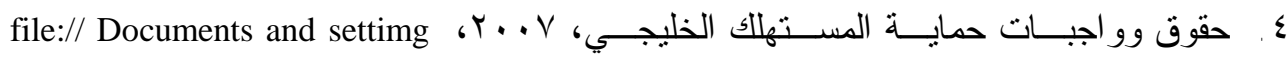
administ rator

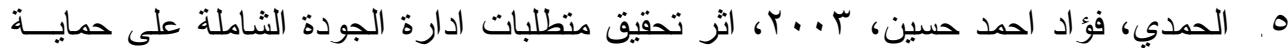

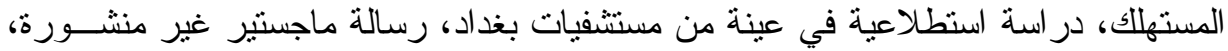

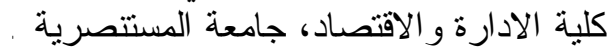

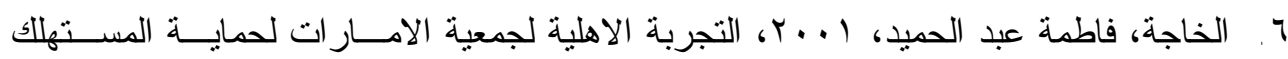

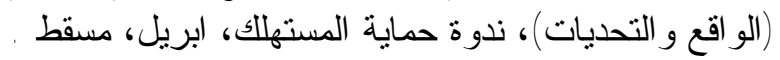

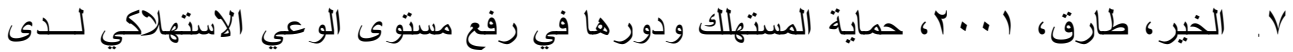

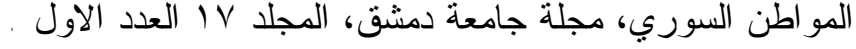

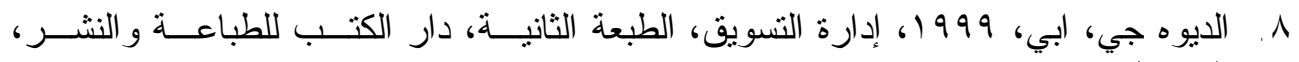

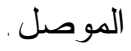

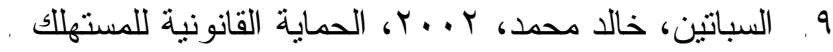

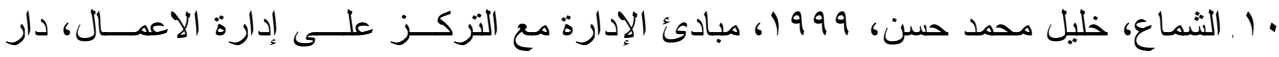

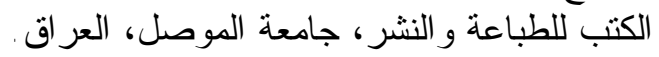

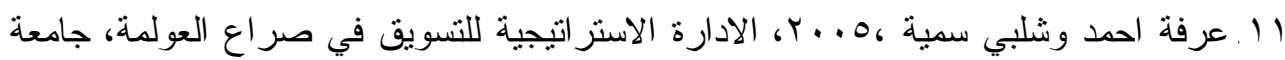

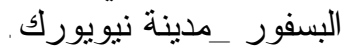

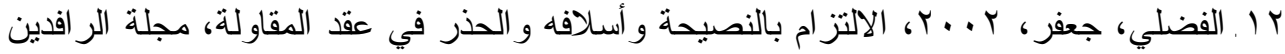

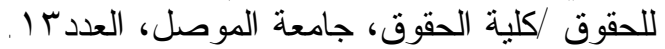

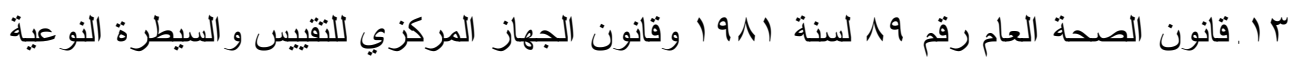

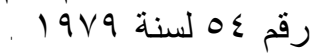

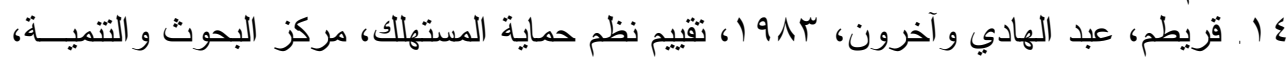

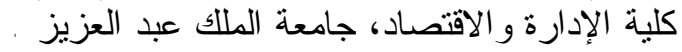

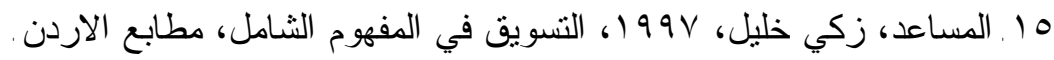

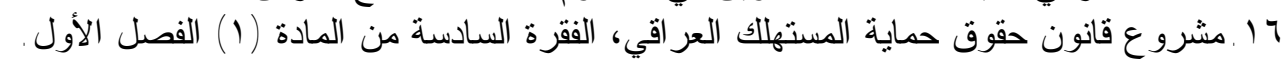

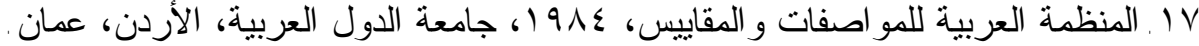

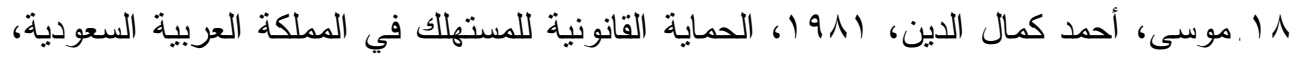

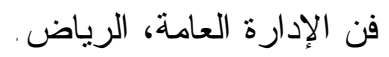

